\title{
Education and Its Poverty-Reducing Effects: The Case of Paraíba, Brazil
}

by

\section{Dorte Verner $^{1}$}

World Bank Policy Research Working Paper 3321, June 2004

The Policy Research Working Paper Series disseminates the findings of work in progress to encourage the exchange of ideas about development issues. An objective of the series is to get the findings out quickly, even if the presentations are less than fully polished. The papers carry the names of the authors and should be cited accordingly. The findings, interpretations, and conclusions expressed in this paper are entirely those of the authors. They do not necessarily represent the view of the World Bank, its Executive Directors, or the countries they represent. Policy Research Working Papers are available online at http://econ.worldbank.org.

\footnotetext{
${ }^{1}$ This paper was prepared for a sector report on education in Brazil, managed by Madalena dos Santos. The author would like to thank the Secretariat of Education in Paraíba for helpful assistance collecting information and Madalena dos Santos and Alberto Rodrigues for helpful comments and suggestions.
} 


\begin{abstract}
Breaking the inter-generational transmission of poverty requires far-reaching actions in the education sector. Widespread poverty affects both students' performance and their availability to attend school. Low-quality education leads to low income, which in turn perpetuates poverty. Furthermore, low levels of education affect growth though low labor productivity.

Although Paraíba, Brazil suffers from a history of educational neglect, the state has recently made significant gains in primary enrollment; 93 percent of the children aged 714 are enrolled in school. However, 30 percent of the population aged 15 and older are illiterate and, unfortunately, it is not only the older generations that cannot read and write: 15 percent of children aged 10 to 15 are illiterate. However, substantial achievements in education have not helped the extremely poor segment of population as much as expected. Probit analyses reveal that education attainment is the single most important poverty-reducing factor. All levels of education from primary to tertiary are significant and negatively associated with the probability of being poor.
\end{abstract}




\section{Introduction}

The education sector has advanced rapidly throughout Brazil during the last decade. Investments in people have taken place at a pace and intensity never experienced before in Brazil and its states and municipalities. The current low worker productivity and high income inequality both follow from Brazil's education system, including low levels of education investments in the past. Without improved productivity, economic growth is likely to remain weak and there will be little room for additional social spending or infrastructure investment. The improvement in the quality of education and the design and delivery of public services and transfers are key for increasing worker productivity, reducing income inequality, and boosting economic growth. Furthermore, education plays a key role in increasing social capital and fostering the inclusion of poor people in society.

The state of Paraíba is a low-to-middle-income state with a population of 3.4 million (2.0 percent of Brazil's total). In 1999, the state's GDP was slightly above R\$7.9 billion, equivalent to about 6 percent of the Northeast's GDP, and well under 1 percent of that of the country. The per capita income of $\mathrm{R} \$ 2,297$ is among the lowest in Brazil.

In the last decade, Paraíba has progressed in improving the quality of life. The quality of life, measured by an index encompassing 21 social indicators including education, increased 37 percent in Paraíba, the largest improvement by a single state in Brazil during 1991-2000.

Despite substantial progress in poverty reduction in the past two decades, about 39 percent of the population in Paraíba is indigent — unable to afford the basic daily caloric intake. During 1981-99, the state's headcount poverty ratio (P0) fell 19 percentage points, four times the rate for Brazil as a whole. ${ }^{2}$ Poverty is more widespread in rural areas, where 62 percent of the population is unable to pay for a minimum basket of food. In urban areas, where 29 percent of the population resides, the incidence of poverty is 30 percent.

The bitter truth is that as overall poverty in Paraíba falls, for some groups, such as for the less educated, children, youth, and mulattos ${ }^{3}$, it is increasing. Households headed by less educated individuals, or where there are young children have been left behind. Furthermore, the gap in P0 between the educated and less educated is widening: the more educated experience less poverty and vice versa.

Although Paraíba suffers from a history of educational neglect, the state has recently made significant gains in primary enrollment; 93 percent of the children age 7-14 are enrolled in school. This is an important first step in reducing the education deficit and future poverty. Thirty percent of the population aged 15 and older are illiterate in Paraíba.

\footnotetext{
${ }^{2}$ The headcount poverty ratio (P0) is defined as the proportion of people below the poverty line. The poverty line used to evaluate poverty in this report is the indigence poverty line, which is based on the monetary cost of a "minimum food-basket" equal to the Food and Agriculture Organization (FAO) minimum caloric intake of 2,288 per day. The poverty line corresponded to a monthly per-capita income of about R $\$ 73$ in 1999, the most recent year for which household information is available.

${ }^{3}$ Mulattos refers to what is called Pardos in Portuguese.
} 
Unfortunately, it is not only the older generations that cannot read and write: 15 percent of the children aged 10 to 15 are illiterate.

In Paraíba more education pays off. The salary and education structure reveals that 80 percent of the population with little attained education (less than one year of study) earns less than one minimum salary. This compares to 65,48 , and 28 percent of the people that completed 1-4, 4-7, and 8-10 years of schooling, respectively. This indicates a positive correlation between wages and schooling. Moreover, education attainment in Paraíba, as in the Northeast as a whole, is the single most important poverty-reducing factor.

Improvements in the access and quality of education are key to poverty reduction in Paraíba and the Northeast in general. This has been recognized at both the national and state levels, with priority on education spending in the public spending budget, and several important policy changes in recent years have aimed at improving access to primary education, increasing enrollment in secondary school, and diminishing regional disparities. The demographic transition presents Paraíba with an excellent opportunity to improve the quality of primary education. The number of students age 14 and below is rapidly decreasing, such as the group aged 0 to 10 that experienced a fall of 14 percent during 1991-2000.

Economic risk, can deplete human capital assets. Hence, households with irregular and low income may withdraw their children from school. Education, training, skills, experience, and good health are all important risk-reducing factors and key for breaking the vicious circle of poor parents with low education attainment raising poor children that obtain low education attainment.

This paper analyzes the state of education and links it to poverty and demographics in Paraíba. Section 2 shows how poverty has evolved, a profile of who is poor and how severely, and the demographic changes. Section 3 presents the education structure, status, educational spending, programs and policies. Section 4 links poverty and education by identifying the main determinants of poverty. These determinants identify the groups that are most at risk of extreme poverty and therefore most in need of the policies aimed at reducing their vulnerability, including education. Finally, section 5 presents policy recommendations on improving education and outcomes.

\section{Poverty and Demography}

The degree of poverty a society might experience depends on the volume and distribution of resources and on the size and distribution of the population among households. These two basic determinants of poverty, however, are not independently determined. On the one hand, the size and age structure of a population are consequences of fertility decisions taken over past decades, which were influenced by economic conditions. On the other hand, the volume of resources available today is influenced by the size and age composition of the labor force. Hence, this sub-section analyzes poverty and demographic trends in Paraíba. 


\subsection{Quality of Life, Poverty, and Inequality}

This paper would prefer the broad view of poverty as unacceptable deprivation in human well being, including not only insufficient income and consumption, but also voicelessness, powerlessness, and the lack of basic needs such as education, health, nutrition, and security. However, data are not available for all these measures of poverty in Paraíba, so for quantitative analysis this paper accepts a much narrower definition of poverty as insufficient income. This section analyzes quality of life and the relationship between income and other household characteristics, but does not attempt a more comprehensive quantitative analysis of other forms of deprivation or social exclusion. Finally, it does not address the broader issues of inequality of assets and opportunity. This paper also sets its poverty bar very low. To define "extreme poverty" it uses the indigence, or "food only", poverty line - those with sufficient income to buy basic food are above the line. The headcount poverty ratio $(\mathrm{P} 0)$ is the proportion of those below the indigence line to the total population.

The Quality of Life Index (Índice de Qualidade de Vida-IQV) is a composite index containing 21 indicators of socio-economic well-being related to outcomes in sectors such as education, health, and water supply. In 1991 and 2000, the IQV index is highest in the Federal District and lowest in Alagoas (Figure 2.1). The length of the bar in Figure 2.1 indicates the advance made in a state during 1991-2000. Hence, the bottom of the bar shows the IQV in 1991 and the top the IQV in 2000.

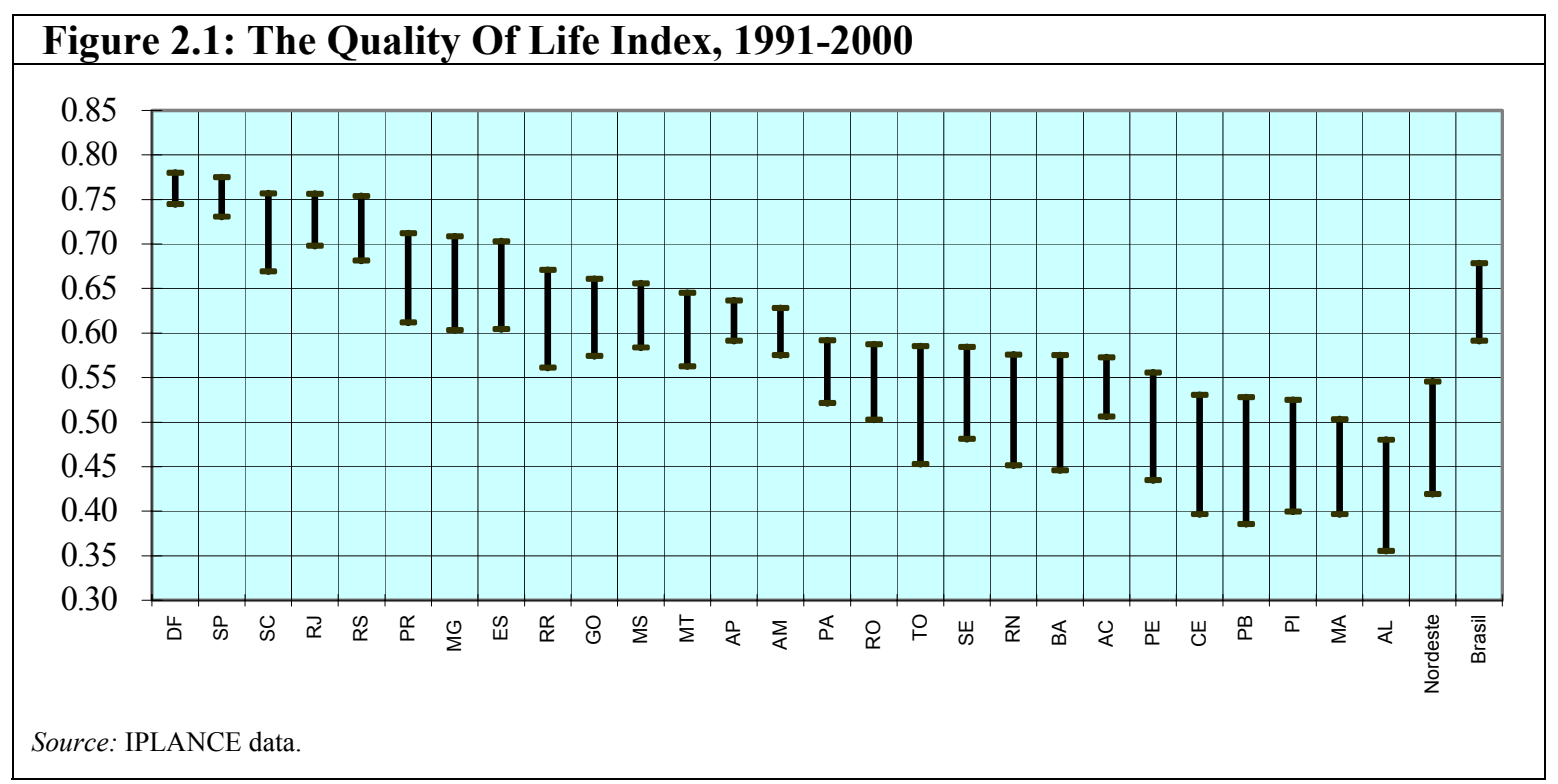

Figure 2.2 reveals that during the 1990s, many of the northeastern states have improved greatly (30.1 percent). Paraíba experienced an increase of 37 percent in IQV, which is the largest increase of a single state in Brazil and nearly double that of Brazil (14.7 percent). 


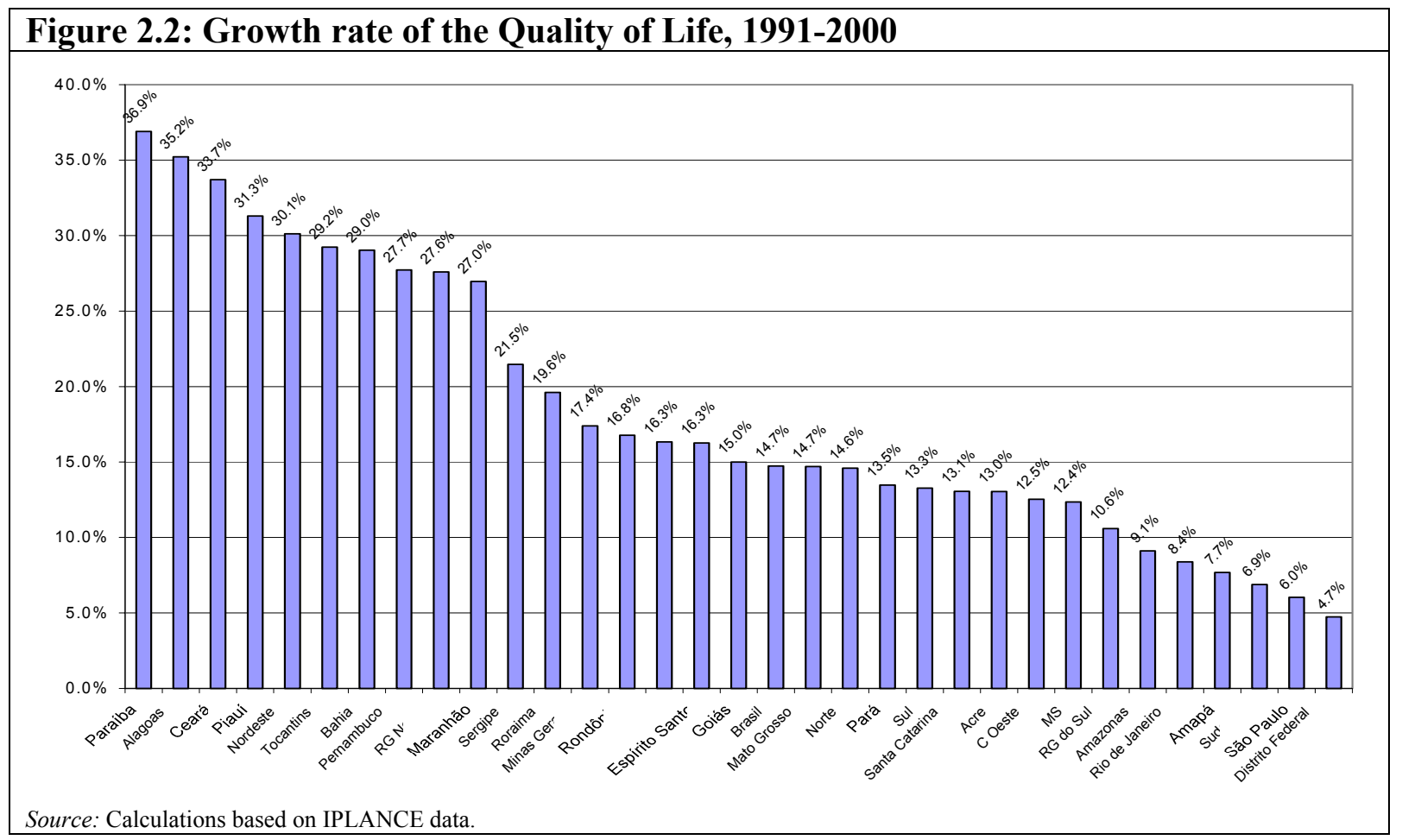

\section{Poverty Trends}

In the last two decades Paraíba has made creditable headway in reducing poverty. During 1981-91, the state's extreme poverty, measured by the P0, fell 19 percentage points. There is little room for complacency, however, because extreme poverty is still very high at almost 40 percent. ${ }^{4}$ This means that over a 1.3 million people still live in extreme poverty, which means that they do not have sufficient income to buy a minimum basket of food. This is almost twice the poverty rate for Brazil as a whole (22.4 percent). Appendix A shows P0, P1, and P2 for Brazil, the Northeast, and the state of Paraíba.

Poverty did not fall monotonically over the last two decades. The P0 increased from the beginning of the 1980 s, fell briefly after implementation of the inflation-beating Cruzado Plan of 1986, increased when the plan collapsed, and increased even more during the crisis of 1990 . The P0 embarked on a downward path only after the most recent inflationbeating Real Plan of 1994 was implemented and the minimum wage increased. There was a sharp a decline in poverty to a level lower than at any point during the previous decade. After the Real Plan was implemented, the P0 fell 7 and 12 percentage points in

\footnotetext{
${ }^{3}$ The data applied for the analysis are both money-metric and non-money-metric welfare indicators constructed from available data. The data applied are from three sources: (a) the Desenvolvimento Humano no Brasil (DHB) (1998), a coproduction of IPEA, IBGE, FJP, and PNUD constructed from the census figures for 1970, 1980, and 1991; and (b) Pesquisa Nacional por Amostra de Domicílios (PNAD) for the years 1981, 1985, 1988, 1990, 1993, 1995, 1997, 1998, and 1999, (no PNAD dataset for the Census year 2000 exists); and (c) Census 2000.
} 
Brazil and the Northeast region, respectively. But Paraíba managed to reduce the P0 by 17.5 percentage points, more than twice the reduction in the national rate. Since 1996, poverty has remained largely unchanged, at around 39 percent (Figure 2.3).

The fall in Paraíba's P0 during 1981-99 was nearly twice the average for the Northeast and five times that of Brazil as a whole (Figure 2.3). Paraíba experienced an 18.9percentage-point reduction in the $\mathrm{P} 0$, while the reduction in the region and the nation was 5.5 and 2.0 percentage points, respectively.

The fall in Paraíba's social indicators such as infant mortality and adult illiteracy during 1980-99 corroborates the improvement in measured income poverty. The infant mortality rate dropped dramatically from 170.6 per 1,000 live births in 1980 to 60.3 per 1,000 live births in 1999, a far greater decline than in the Northeast and Brazil as a whole (Table 2.1). Adult illiteracy took the same path as the P0 and infant mortality. During 1980-99 the illiteracy rate for people over age 15 fell 23 percentage points, to 25.9 in 1999 . The downward trends in the poverty rate, infant mortality, and adult illiteracy testify to government success in areas including health and education.

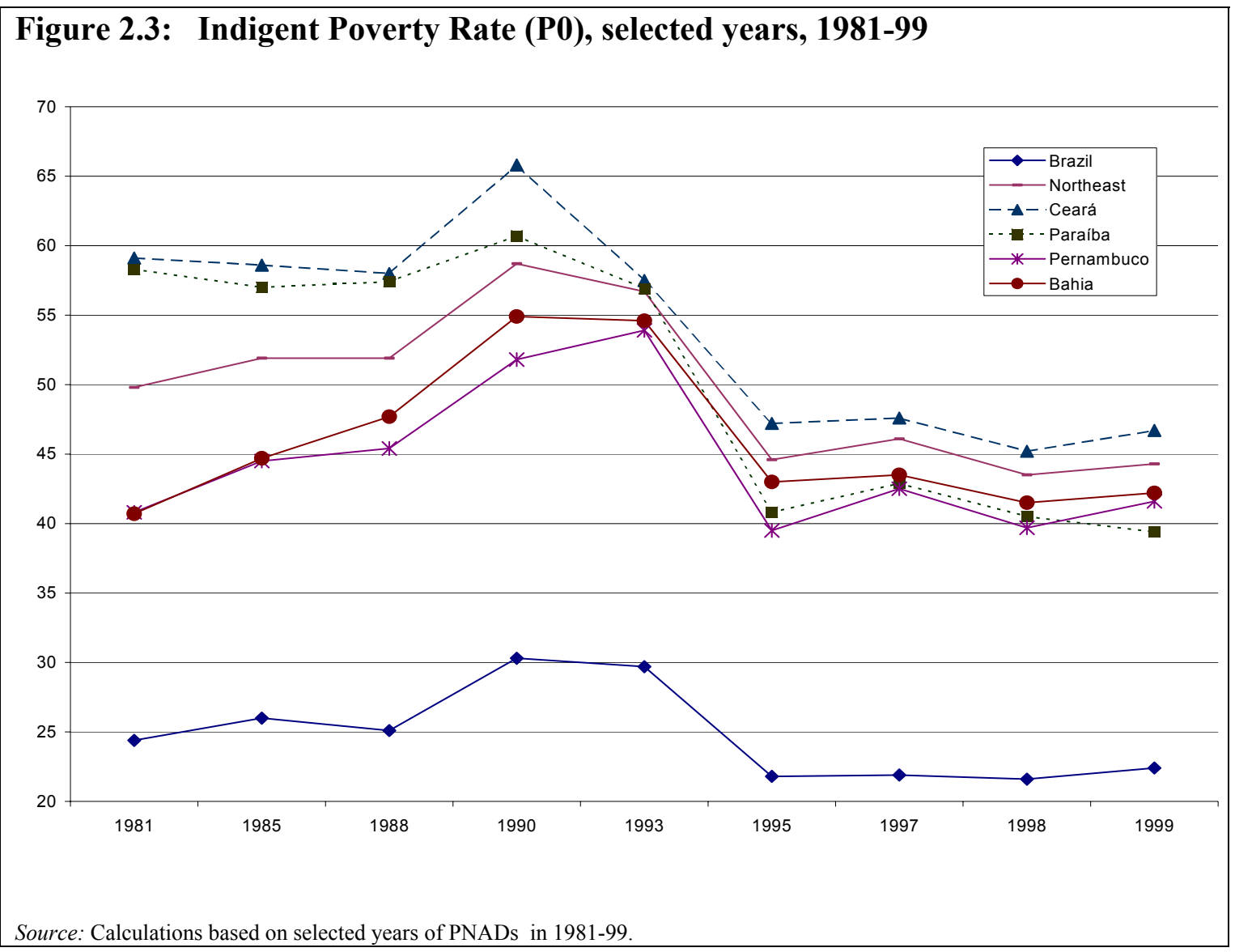




\begin{tabular}{|l|c|c|c|c|}
\hline Table 2.1: Illiteracy and Infant Mortality, 1980 and 1999 \\
\hline & \multicolumn{2}{|c|}{$\begin{array}{c}\text { Illiteracy Rate } \\
\text { People Over Age 15 }\end{array}$} & $\begin{array}{c}\text { Infant Mortality } \\
\text { Per 1,000 Live } \\
\text { Births }\end{array}$ \\
\cline { 2 - 5 } & $\begin{array}{c}\mathbf{1 9 8 0} \\
\mathbf{( \% )}\end{array}$ & $\begin{array}{c}\mathbf{1 9 9 9} \\
\mathbf{( \% )}\end{array}$ & $\mathbf{1 9 8 0}$ & $\mathbf{1 9 9 9}$ \\
\hline Brazil & 25.3 & 13.3 & 85.2 & 34.6 \\
\hline Northeast & 45.9 & 26.6 & 131.3 & 53 \\
\hline Alagoas & 54.0 & 32.8 & 159.5 & 66.1 \\
\hline Bahia & 43.1 & 24.7 & 95.4 & 45.4 \\
\hline Ceará & 45.5 & 27.8 & 155.2 & 52.4 \\
\hline Maranhão & 51.0 & 28.8 & 126.3 & 54.2 \\
\hline Paraíba & 49.3 & 25.9 & 170.6 & 60.3 \\
\hline Pernambuco & 42.2 & 24.7 & 149.8 & 58.2 \\
\hline Piaún & 49.6 & 31.6 & 105.6 & 45.3 \\
\hline Rio Grande do Norte & 44.4 & 25.5 & 169.3 & 48.7 \\
\hline Sergipe & 46.5 & 23.9 & 110.9 & 45.4 \\
\hline
\end{tabular}

Although Paraíba has made substantial progress in reducing the share of the population living in extreme poverty, the problem remains broad and deep. The P0 measures the proportion of people below a certain poverty line but takes no account of how far they are below that line - the degree of poverty - or whether they are becoming even poorer. To address the situation of the poorest and to evaluate whether their economic situation has improved, the squared poverty gap measure (or P2) is used. This takes into account the degree of poverty, because it gives more weight to the poorest and most vulnerable. As a matter of fact, the squared poverty gap measure reveals that poverty was less deep in 1999 than in 1981 (3 percentage points), implying that the poorest became less poor. In fact, Paraíba has done better than the Northeast and Brazil-the squared poverty gap measure increased by 1.3 and 2.3 percentage points in the Northeast and the nation.

Part of the reason that Paraíba's indicators are worse than in other countries with similar per capita incomes is because of income inequality. Both Brazil and Paraíba have extremely unequal income distribution. Paraíba's income inequality has declined, however. In 2000, the Gini Coefficient for Paraíba was 0.60, slightly below the coefficient for the Northeast region (0.62), and Brazil as a whole (Figure 2.4). That compares to a Gini of 0.64 in 1991, a slightly better improvement than that in the rest of the Northeast and Brazil, where it improved by 0.03 percentage points.

Paraíba's performance with reducing inequality is commendable. Changes in inequality are typically very slow, except during periods of radical social and institutional change. Where inequality has fallen it has usually happened in association with major expansion and equalization in educational attainment, as in Korea and Malaysia in the 1970s and 1980s. Paraíba's expansion in education may have been too recent to have a significant effect on the composition of skills, and occurred during a period in which the overall returns to high levels of skills were rising and returns to basic skills were falling in Brazil. 


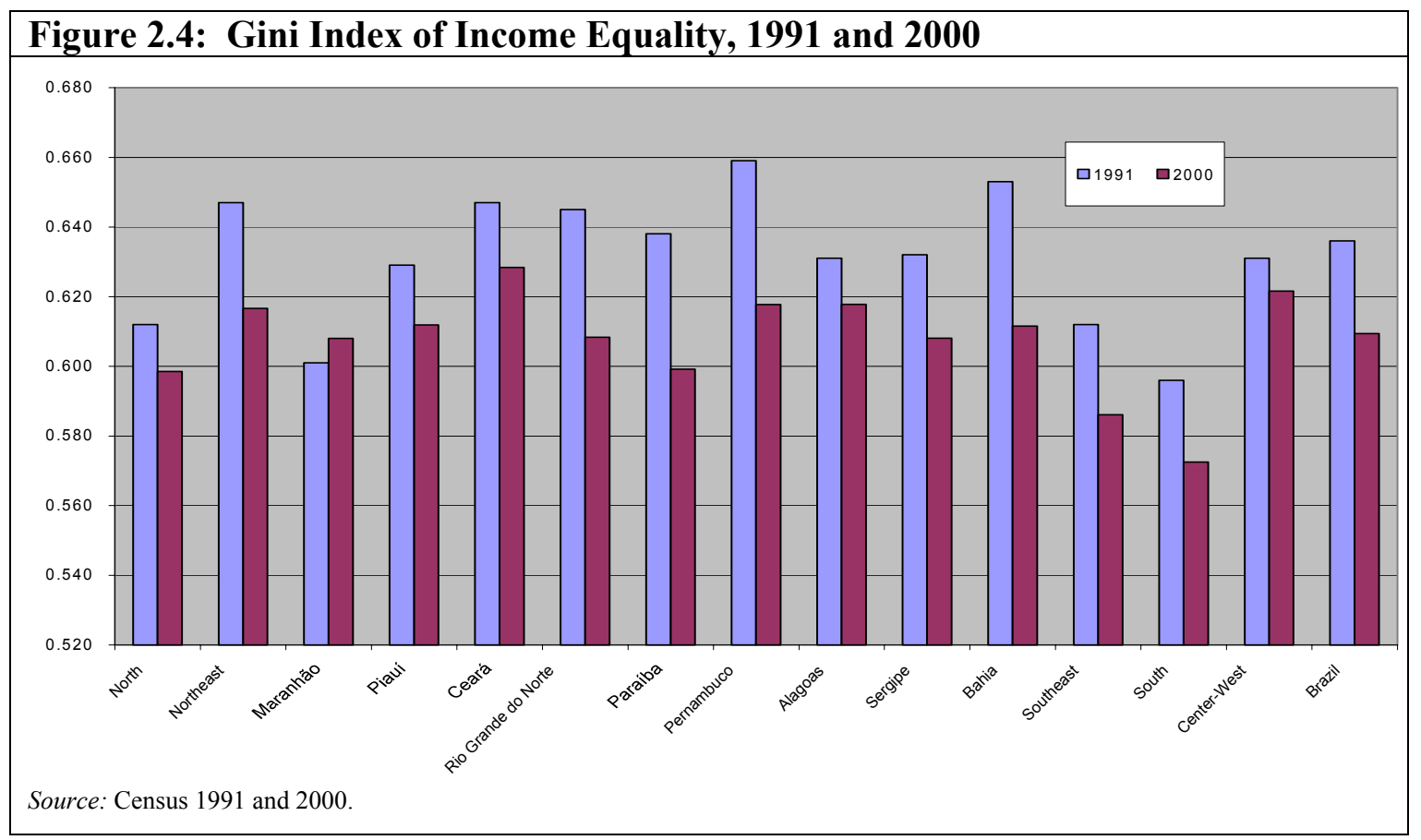

\section{Poverty Profile}

Comparing average levels of poverty for different categories is useful for learning about which population groups are falling behind or catching up in terms of poverty. This is useful for the design of policies: we would like to know not only whether, for example, more- or less-educated people are more likely to be poor in Paraíba, but how the relative odds of being poor have evolved for these groups. This section traces the evolution of the P0 for various population groups during the 1990s. Appendix B presents the full profile for Brazil, the Northeast, and Paraíba during 1981-99.

The structure of poverty is clear in Paraíba: (a) blacks and mulattos are poorer than whites, (b) young households/household heads are poorer than older households/household heads, (c) the poor tend to work more in the informal sector, and (d) the poor are more engaged in agriculture than in industry and services. Furthermore, the deepest poverty is in rural areas, among the illiterate or poorly educated and young households with children. In fact, the $\mathrm{P} 0$ is actually rising for these groups. Under current conditions, their plight is likely to worsen because they lack opportunities and assets.

More blacks and mulattos are poorer than whites. The poverty profile for 1999 reveals a large difference in the levels of well being among different groups. The P0 reveals that about 45 percent of households headed by blacks and mulattos are extremely poor compared to 3 percent of households headed by whites. During 1988-99, poverty fell 21.9 percentage points among households headed by whites and about 16 points among those headed by blacks and mulattos. ${ }^{5}$ Brazil's racial heterogeneity does not create equal opportunities for everybody for example in education and employment. In fact,

${ }^{5}$ For a detailed description of the poverty profiles for Brazil and the Northeast, including Paraíba during 1981-99, see Fiess and Verner (2001). 
education and labor markets seem to be the main sources of racial exclusion in Brazil. An important first step is to address racial issues as early as in primary school and remove racial caricatures from textbooks and other school material.

Being able to read and write is important in determining the likelihood of being in poverty. The P0 is 31 percent for household heads that are literate, and 54 percent for those that are not. However, while a negative relationship between years of education completed and poverty is typical, and is evident in most of the Northeast states, it is less marked in Paraíba, where there appears to be only a relative little difference in P0 between household heads with no education (51 percent) and household heads with completed primary education $\left(40\right.$ percent). ${ }^{6}$ Nevertheless, household heads that have completed secondary education are much better off ( 20 percent are poor) than those with only primary education ( 40 percent are poor). Only 3 percent household heads with more than 12 years of schooling were extremely poor. Hence, these figures show that education is an important poverty-reducing factor (see also section 4). Policies to increase school attendance and improve quality of supplied education are important elements in Paraíba's poverty reduction effort.

In the last half decade, the gap in P0 between the educated and less educated has widened: the more educated are experiencing less poverty, while the less educated are being left behind. For each level of education (lower primary only, upper primary only, secondary only, and tertiary) the probabilities of being poor are estimated for Paraíba. ${ }^{7}$ Figure 2.5 shows that there are very large differences in poverty levels by education, and that they have increased over time: since 1995, the P0 for people with some primary education appears to have increased, while the P0 for people with some university education has stayed at its already very low level. In Paraíba, as elsewhere, there is a great deal of debate about the causes of these changes: skill-biased technological change, changes in the relative supply of and demand for workers with different characteristics, and trade liberalization have all been mentioned as possible explanations (Blom and Velez 2001; Blom, Pavcnik, and Schady 2001).

\footnotetext{
${ }^{6}$ This picture might be clouded by the relatively small sample size of these groupings in the PNAD datasets for Paraíba.

${ }^{7}$ The estimations show that the differences in the probabilities of being poor between men and women, by race, and by place of residence have all basically remained constant throughout the 1990s. For these categories, therefore, analysis of the poverty profile at one point in time is sufficient.
} 


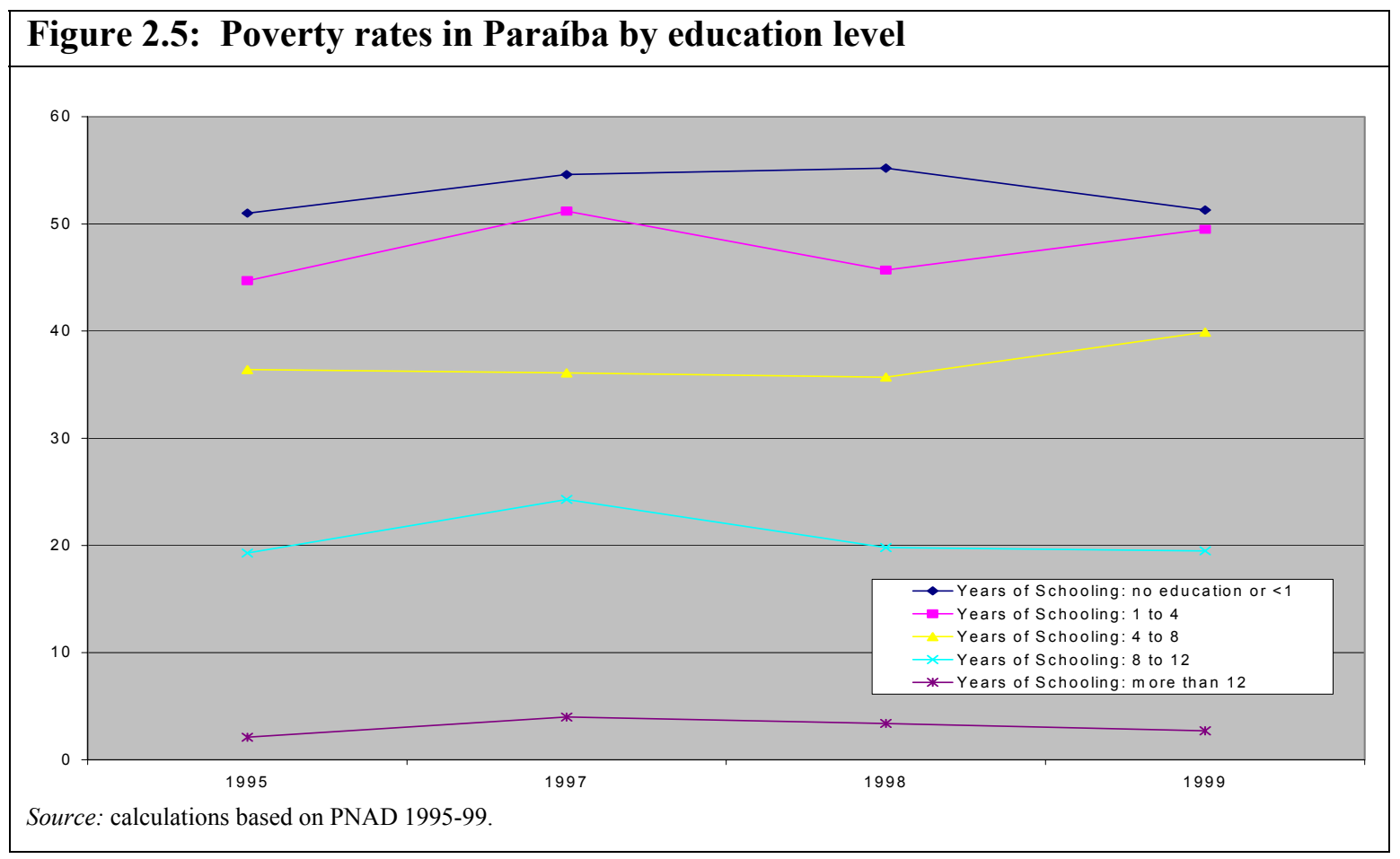

The younger the household head, the poorer the household. Data reveal that 63 percent of the households headed by a person younger than age 25 are extremely poor in Paraíba. This number may be overstated because no adjustment has been made for the fact that young children, which these households are likely to have, do not need to consume 2,288 calories, as do adults. However, what is worrying is that they are getting worse off. The poverty rate for these households rose 14 percentage points during 1981-99. This is not as bad as the Northeast as a whole, where 66.1 percent of the households headed by a person younger than age 25 are extremely poor, which is a 22 -percentage-point increase during the same period.

In Paraíba, only 20 percent of those older than age 65 are below the indigent poverty line - a decline of 15 percentage points since 1993. Additionally, the latter group has the highest average income of any age group, which may be explained in part by pension reforms. The P0 of the population groups aged 25 to 44 and 45 to 64 fell by 15 and 23 percentage points, respectively, during 1981-99. In 1999, 47 percent of the younger group were extremely poor, but 37 percent of the older group. Thus the younger the head of household, the more likely it is to be poor. This life-cycle profile of poverty illustrates that many households are born poor (due again to inadequate assets), with some escaping poverty as they accumulate more assets or as their household size shrinks. It illustrates the need to raise the entry income of the poor through increased labor demand growth and better education opportunities.

The age of household members also affects household poverty. The more young children there are, the poorer the household, although this may be partly explained that Brazil does not adjust for the fact that it takes less income to feed young children or that there are economies of scale for larger households. Among households with children under age 5, 
55.5 percent were extremely poor compared to 44.7 percent of those with children aged 5 to 15 . Among households with a member older than age 65 the rate drops even further, to 27 percent. During 1981-99, the rate of extreme poverty among households with children under age 5 fell 4.6 percentage points, but for households with children aged 5 to 15 it fell 14.2 percentage points. The P0 shows striking differences by age group: it is more than two times higher for children under age 5 than for people older than age 65 .

Very young children have the highest-and growing - probability of being poor in Paraíba. There is considerable evidence from other settings that the benefits associated with early childhood interventions are very high indeed, especially for children from disadvantaged backgrounds, both because this is a critical stage in child development and because the returns to any productive investment in children accrue over a much longer period of time than the returns to productive investments in adults (see Heckman 1999; Currie 2001). This suggests that interventions that benefit very young children, for example early childhood developing programs, should receive high priority.

Informal workers suffer more poverty than formal workers. The P0 for informal workers (sem carteira assinada-without a signed workbook) is high - 63 percent compared to 27 percent for formal workers. However, in the last two decades it has fallen 8 percentage points among formal workers and, surprisingly, has fallen 16 percentage points among informal workers, which is very heartening. The fact that the poor tend to work more in the informal sector illustrates the need to reduce costs of employment creation in the formal sector, so that formal employment can grow faster and the formal/informal divide becomes less relevant. Finally, since most poor people do not work in the formal labor market, social policies tied to formal employment or unemployment will have only very limited reach among the poor.

Women are only marginally more likely to be poorer than men, with 40 percent and 39 percent of female- and male-headed households, respectively, likely to be poor. Since 1993, male-headed households experienced a reduction in poverty (18 percentage points) little different to female-headed households (19 percentage points). These income poverty figures are, however, only part of the myriad of factors that affect a poor woman's well being. The data do not reveal anything about domestic violence and other types of discrimination that women often face, nor the fact that women should have higher incomes, as they tend to have more education than men.

Those who work in agriculture are more likely to be poor, suggesting that productivity in agriculture is lower than in services or industry. The P0 is 60 percent in agriculture, but 27 percent among service workers, and 53 percent among industrial workers. However, the agricultural and industry workers' poverty rate fell by an encouraging 16 percentage points in the last two decades as compared to 13 percentage points in services.

One-third of Paraíba's population lives in rural areas, with limited access to basic infrastructure and services. The rural poor are primarily smallholders, sharecroppers, and wageworkers that depend on a diverse strategy of income-generating activities in which the subsistence production of corn, beans, manioc, rice, and small livestock predominates. Their well-being fluctuates with changes in the agro-climatic conditions. In the semiarid and transition zones, rainfall is scarce and highly irregular, yielding crops 
of low quality and low-income-generating capacity. In addition to the lack of a reliable water supply, these small farmers lack modern production technology, basic infrastructure to store harvests to take advantage of cyclical price fluctuations, and organized marketing facilities. Family income is therefore highly variable and there is little opportunity for saving. Since 1993, poverty in rural areas has been reduced by an impressive 13 percentage points, to 62 percent, and in urban areas by 18 percentage points, to 30 percent in 1999. This seems to suggest that the Real Plan and state policies have benefited urban areas slightly more than rural areas.

Among the most vulnerable groups in Paraíba are landless farmers, informal workers on the urban periphery, and young parents. The landless farmers in the semiarid Sertão earn a very low and irregular income. They have very few assets, including education, and are exposed to droughts, and therefore they are at high risk of poverty and vulnerability because they have little or no protection. The informal urban sector workers earn a low and irregular income, own very few assets, and have no insurance against poverty. They face risks in the form of unemployment, crime, violence, and overall economic downturns. Young parents with low income, low level of education, and few assets may also suffer poor health. Their children receive low-quality education, and the parents have no access to kindergartens for the youngest offspring. Such young parents face a high probability of becoming unemployed, and have no access to employment benefits or other social benefits. These three groups are all vulnerable and at considerable risk of poverty. A basic, efficient, and well-targeted social safety net could be important to insure these people against the risk of poverty. A social safety net could also guarantee a basic level of consumption for those not able to benefit from opportunities created by growth and social investments (World Bank 2001).

\subsection{Demography}

Demographic factors have direct and indirect impacts on prices and poverty. As the size and age composition of the population changes, the relative size of labor force and the number of dependents also change, modifying the dependency ratio of families, and therefore their level of poverty. This is the direct effect of demographic changes. It captures the effect that demographic changes have on quantities: number of children, size of the labor force, and the number of elderly persons. These changes in quantities, however, will, in general, influence prices in the economy. In particular, changes in the rate of growth of the population and in the age structure may have important impacts on labor supplies and on savings. As a consequence, demographic changes may have considerable impact on the level of wages and on interest rates. Since these prices are important determinants of family income, they are bound to have a profound influence on the level of poverty. These are the indirect impacts of demographic changes on poverty, since they occur through the indirect effects of demographic changes on the level of labor supply, savings, wages, and interest rates.

Demographic changes in a given Brazilian state are influenced by federal, state, and municipality development policies and public sector investments, along with other economic and social variables, for example, economic conditions inside and outside the state and municipality, migration in and out of the state, fertility and mortality rates, and 
education levels. Changing demographics can have important impacts on the demands for public sector investments and incentives for private sector investments, public services and the political power to lobby for support, and on labor markets. As a result, it is important to look at recent changes in demographic patterns in Paraíba. The following describes demographic changes that have taken place in Paraíba from 1991 to 2000. All raw population data are from IBGE, with Census data used for 1991 and 2000. The focus is on changes in population size, geographic dispersion, and age distributions.

In Paraíba, the population was 3.4 million in 2000. Compared to other states in the Northeast, the population growth rate in Paraíba was relatively low-about 1 percent per year in 1996-2000 (Table 2.2).

\section{Table 2.2: Demographics in the Northeast}

\begin{tabular}{|l|c|c|c|c|}
\hline & $\begin{array}{c}\text { Population, } \\
2000 \\
(1,000)\end{array}$ & $\begin{array}{c}\text { Annual } \\
\text { Population } \\
\text { Growth Rate } \\
1996-2000^{*} \\
\text { (Percent) }\end{array}$ & $\begin{array}{c}\text { Urban Population, } \\
2000 \\
\text { (percent) }\end{array}$ & $\begin{array}{c}\text { Female Population, } \\
2000 \\
\text { (percent) }\end{array}$ \\
\hline Sergipe & 1,780 & 2.31 & 71 & 51 \\
\hline Ceará & 7,417 & 2.16 & 72 & 51 \\
\hline Rio Grande do Norte & 2,771 & 2.01 & 73 & 51 \\
\hline Maranhão & 5,638 & 1.94 & 60 & 50 \\
\hline Alagoas & 2,818 & 1.71 & 68 & 51 \\
\hline Pernambuco & 7,911 & 1.69 & 77 & 52 \\
\hline Piauí & 2,841 & 1.53 & 63 & 51 \\
\hline Bahia & 13,067 & 1.03 & 67 & $\mathbf{5 1}$ \\
\hline Paraíba & $\mathbf{3 , 4 3 7}$ & $\mathbf{0 . 9 8}$ & $\mathbf{7 1}$ & - \\
\hline TOTAL Northeast & 48,680 & ---- & --- & \\
\hline Source: calculations based on Census 2000. Note: * Average geometric rate of annual increment. & \\
\hline
\end{tabular}

\begin{tabular}{|lccc|}
\hline \multicolumn{4}{|c|}{ Table 2.3: Population and Age Structure, 1991-2000 } \\
\hline & $\begin{array}{c}\text { Population } \\
\mathbf{1 9 9 1}\end{array}$ & $\begin{array}{c}\text { Population } \\
\mathbf{2 0 0 0}\end{array}$ & $\begin{array}{l}\text { Population } \\
\text { growth rate } \\
\mathbf{1 9 9 1 - 2 0 0 0}\end{array}$ \\
\hline Total Population & $3,201,114$ & $3,443,825$ & $7.6 \%$ \\
& & & \\
Less than 5 years of age & 393,573 & 338,321 & $-14.0 \%$ \\
$\mathbf{5}-\mathbf{9}$ & 412,218 & 355,392 & $-13.8 \%$ \\
$\mathbf{1 0}-\mathbf{1 4}$ & 407,913 & 389,897 & $-4.4 \%$ \\
$\mathbf{1 5}-\mathbf{1 9}$ & 360,981 & 388,789 & $7.7 \%$ \\
$\mathbf{2 0}-\mathbf{2 4}$ & 279,416 & 323,117 & $15.6 \%$ \\
$\mathbf{2 5}$ and above & $1,347,013$ & $1,648,309$ & $22.4 \%$ \\
\hline Source: based on IBGE, Census 1991 and 2000. & \\
\hline \multicolumn{4}{|c}{} \\
\hline
\end{tabular}

As are the other Northeastern states, Paraíba is highly urbanized, and became even more so in 1991-2000, with the percentage of the population living in urban areas counting 71 percent in 2000 (Table 2.2). 
There have been substantial shifts in the age structure of the population (Table 2.3), similar to those taking place in Brazil as a whole. The share of children aged 0-14 years declined from 38 percent in 1991 to an estimated 31 percent in 2000. Furthermore, the absolute number of children in this group fell during 1991-2000.

\section{Education}

In the area of education, the poverty profile indicates that household heads that have completed secondary or more education are much better off than those with no or primary education only. Hence, education is a key in raising earning potentials of individuals and productivity of the economy. A more educated workforce produces high value output, which contributes to growth and poverty reduction. Education, apart from human capital, also creates social capital as it may transmit cultural messages and build social cohesion. Although the positive effects on economic growth of education investment is gradual and takes time to appear, the benefits to the individuals that receive the investment are more instant.

As shown in the previous section, Paraíba has achieved considerable progress in reducing income poverty and improving social indicators. With decisive action, Paraíba could achieve targets for further improvements in social indicators.

State expenditures on education have increased considerably in the last decade, which is appropriate given their importance for poverty reduction. Since the number of those aged 14 and under is not growing, Paraíba has been presented with an excellent opportunity to improve the quality of education. Paraíba, as other states of Brazil, has seized the opportunity effectively. At both the national and state level, governments have raised education's share of the public budget and introduced policy changes aimed at improving access to primary education, increasing enrollment in secondary school, and diminishing regional disparities. Paraíba has been particularly aggressive and has seen enormous improvements in enrollment rates and school attainment.

While the state is spending considerable resources on education, the Brazilian growth analyses show that education has not played a major role in the determination of economic growth in Brazil. ${ }^{8}$ Similarly, analyses show that education, rather than labor market segmentation, explains most of the wage differential in the Northeast. This section suggests two possible reasons: (a) the quality of education provided in schools is not very high and (b) most students do not remain in school long enough to learn skills that will help them obtain better jobs. The latter may itself be due to the low quality of education. Another worrisome finding is that the substantial achievements in education have not led to the extremely poor catching up to the nonpoor in education attainment.

The section on education is organized in three subsections. Section 3.1 outlines the education structure. Section 3.2 addresses educational status and Section 3.3 analyzes expenditures, policies, and programs.

\footnotetext{
${ }^{8}$ See Abreu and Verner (1997) on Brazil.
} 


\subsection{Education Structure in Brazil}

Brazil's basic education system is divided into: pre-school; primary school, an eight-year cycle (ensino fundamental); and secondary, a three-year intermediate cycle (ensino médio). Pre-school education includes the social development of children age 6 and younger. Primary encompasses children between the ages of 7 and 14 and is divided into two stages (grades 1-4 and 5-8), of primary school and at the end of secondary school. Secondary school is comprised of grades 9-11 and is intended for students aged 15-17 (Table 3.1). National testing is conducted at the end of each stage.

\begin{tabular}{|c|c|c|c|}
\hline Age & Grade & Brazilian Structure & Paper Terminology \\
\hline 7 & 1 st. & \multirow{4}{*}{$\begin{array}{c}\text { Ensino Fundamental } \\
\quad\left(\text { Series } 1^{\text {st }}-4^{\text {th }}\right)\end{array}$} & \multirow[t]{4}{*}{ Primary } \\
\hline 8 & 2nd. & & \\
\hline 9 & 3 rd. & & \\
\hline 10 & 4th. & & \\
\hline 11 & 5th. & \multirow{4}{*}{$\begin{array}{l}\text { Ensino Fundamental } \\
\quad\left(\text { Series } 5^{\text {th }}-8^{\text {th }}\right)\end{array}$} & \multirow[t]{4}{*}{ Lower Secondary } \\
\hline 12 & 6th. & & \\
\hline 13 & 7th. & & \\
\hline 14 & 8th. & & \\
\hline 15 & $1^{\text {st }}$ & \multirow[t]{3}{*}{ Ensino Médio } & \multirow[t]{3}{*}{ Upper Secondary } \\
\hline 16 & 2nd. & & \\
\hline 17 & 3 rd. & & \\
\hline
\end{tabular}

State systems in Brazil enroll 47 percent of grade 1-4 students, while municipal systems enroll 43 percent (Alberto Rodríguez 2002). The picture for grade 5-8 is quite different, with state systems accounting for nearly 70 percent of enrollments and municipal systems accounting for 20 percent. Secondary education is also mainly taken care of by the state, 72 percent of enrollments are in state schools, 20 percent in private schools, 6 percent in municipality schools, and 2 percent of enrollment is taken care of by the federal government.

Public school's primary education is heavily dependent on the delivery of the service by municipalities, which create a challenge for the state since the capacity is not the same in relatively richer and poorer municipalities. To address this problem the state government has created 12 regional management offices in Paraíba. These offices plan, coordinate, and monitor the state's policies and investments and, furthermore, play a core role in coordinating efforts between the state and municipalities in the area of education, as the municipalities are essentially autonomous. 


\subsection{Educational Status}

Literacy rates. Paraíba has made great strides in literacy during the last three decades, reducing illiteracy from 55 to 28 percent (Table 3.2). However, it is among the five states with the highest illiteracy rate in Brazil. Rather than being a corollary of economic growth, which was high only in the 1970s and weak during the 1980s and 1990s, gains arose from changes in policy. Illiteracy rates in Paraiba, and Brazil as a whole, are still high compared to other contries in the region, for example in Chile only 4.1 percent are illiterate and 8.3 percent in Mexico.

\begin{tabular}{|l|c|c|}
\hline \begin{tabular}{|} 
Table 3.2: Literacy in Brazil \\
$\mathbf{1 9 7 0}$ and $\mathbf{2 0 0 0}$ (percent)
\end{tabular} \\
\hline & $\mathbf{1 9 7 0}$ & $\mathbf{2 0 0 0}$ \\
North & 63.0 & 83.7 \\
Northeast & 46.1 & 73.8 \\
Ceará & 44.6 & 73.5 \\
Rio Grande do Norte & 45.6 & 74.6 \\
Paraíba & 45.0 & 72.4 \\
Pernambuco & 50.3 & 75.5 \\
Bahia & 49.4 & 76.9 \\
Southeast & 77.1 & 91.9 \\
South & 76.5 & 92.3 \\
Center West & 67.5 & 89.2 \\
Brazil & 67.0 & 86.4 \\
\hline \multicolumn{2}{|l|}{ Source: Census 1970 and 2000. } \\
\hline
\end{tabular}

Efforts to lower illiteracy further are hampered by the fact that many of the illiterates are adult - the result of years of educational neglect. Efforts to improve adult literacy have been undertaken, but with poor results, because it is more difficult to teach basic skills to adults than to children.

In 2000, about 15 percent of those aged 10-14 were illiterate, and 18 percent of those aged 20-24 were illiterate. The majority of illiteracy is still in the 50 and older age group, 42 percent can not read and write. Moreover, there is a gender difference in the illiteracy rates-24 percent of females are illiterate compared to 32 percent of males (Figure 3.1). Illiteracy is also worse in rural than in urban areas- 48 percent compared to 25 percent for males, and 34 percent compared to 20 percent for females. 


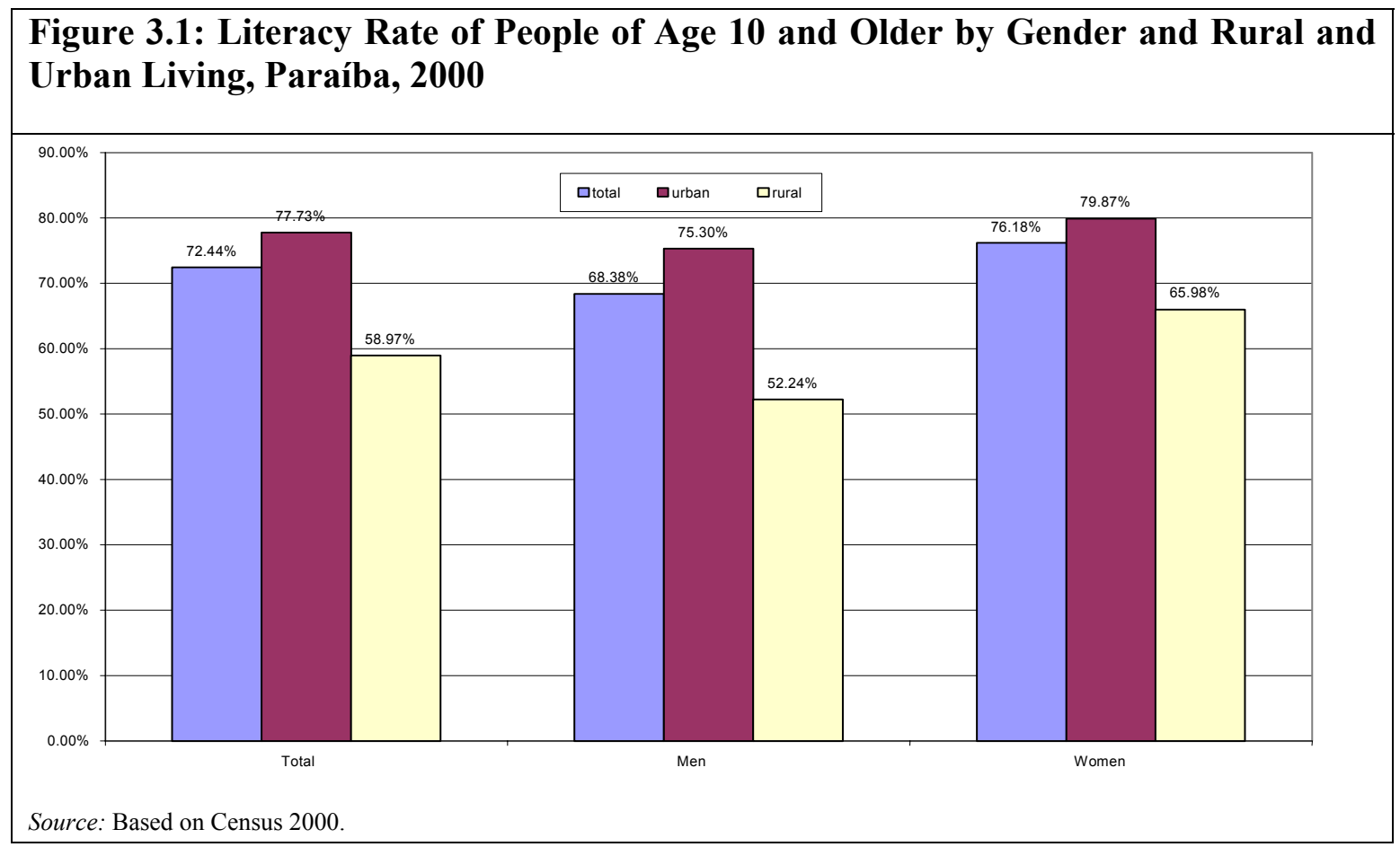

School Enrollment. In Paraíba, school enrollment has improved enormously in the last two decades. During 1980-99, enrollment in primary schools increased by 15 and 17 percentage point to 95 and 93 percent, for Brazil as a whole and Paraíba respectively (Figure 3.2). In 2000, a number of 889.003 children and adolescents were enrolled in primary school in Paraíba. Figure 3.3 shows that Paraíba's school-enrollment catch up occurred mainly after 1994. These gains arose from changes in policy, in particular among federal initiatives to boost enrollment and guarantee funding per child, such as FUNDESCOLA and FUNDEF (see below), combined with effective decentralization to states and municipalities.

\begin{tabular}{|c|c|c|c|c|c|c|c|c|c|}
\hline Age & $\begin{array}{c}\text { Total } \\
\text { BR }\end{array}$ & $\begin{array}{c}\text { Total } \\
\text { NE }\end{array}$ & $\begin{array}{c}\text { Total } \\
\text { Paraíba }\end{array}$ & $\begin{array}{c}\text { Urban } \\
\text { BR }\end{array}$ & $\begin{array}{c}\text { Urban } \\
\text { NE }\end{array}$ & $\begin{array}{c}\text { Urban } \\
\text { Paraíba }\end{array}$ & $\begin{array}{c}\text { Rural } \\
\text { BR }\end{array}$ & $\begin{array}{c}\text { Rural } \\
\text { NE }\end{array}$ & $\begin{array}{c}\text { Rural } \\
\text { Paraíba }\end{array}$ \\
\hline $5-6$ & 69.1 & 72.8 & 79.7 & 73.4 & 79.5 & 86.2 & 56.4 & 63.5 & 71.2 \\
\hline $7-14$ & 94.7 & 92.3 & 94.4 & 95.8 & 93.6 & 94.9 & 91.2 & 90.4 & 93.5 \\
\hline $15-17$ & 76.5 & 72.5 & 72.1 & 79.7 & 77.2 & 79.5 & 64.6 & 64.7 & 58.9 \\
\hline $18-19$ & 49.3 & 48.7 & 45.4 & 52.0 & 53.3 & 49.8 & 37.3 & 39.5 & 35.3 \\
\hline $20-24$ & 24.2 & 24.2 & 26.1 & 25.9 & 26.7 & 30.6 & 16.3 & 18.9 & 17.6 \\
\hline
\end{tabular}

The enrollment picture is not all rosy in Paraíba. In older age groups, Paraíba falls behind in enrollment rates. Enrollment for ages 15-17 is 72.1 percent, considerably below the national average of 76.5 percent (Table 3.3). 
Also, enrollment rates at secondary level improved. During 1980-1999, Paraíba experienced an 8-percentage-points increase to 14.3 percent (or 117,271 students) in 1999, which is considerably lower than Brazil's 19-percentage-points increase to 33 percent. An international comparison of the secondary enrollment rate reveals that Brazil lacks behind. In Chile and Mexico 70 and 58 percent are enrolled in secondary school and Korea tops the list with 98 percent enrollment rate. The low completion rate in eighth grade (see below) explains the very low entry rate in secondary education in Paraíba. In fact, student flow analyses have demonstrated that repetition, rather than physical access, is the principal impediment to the expansion of secondary education in Brazil.

\section{Figure 3.2: Primary and Secondary School enrollment rates, 1999}

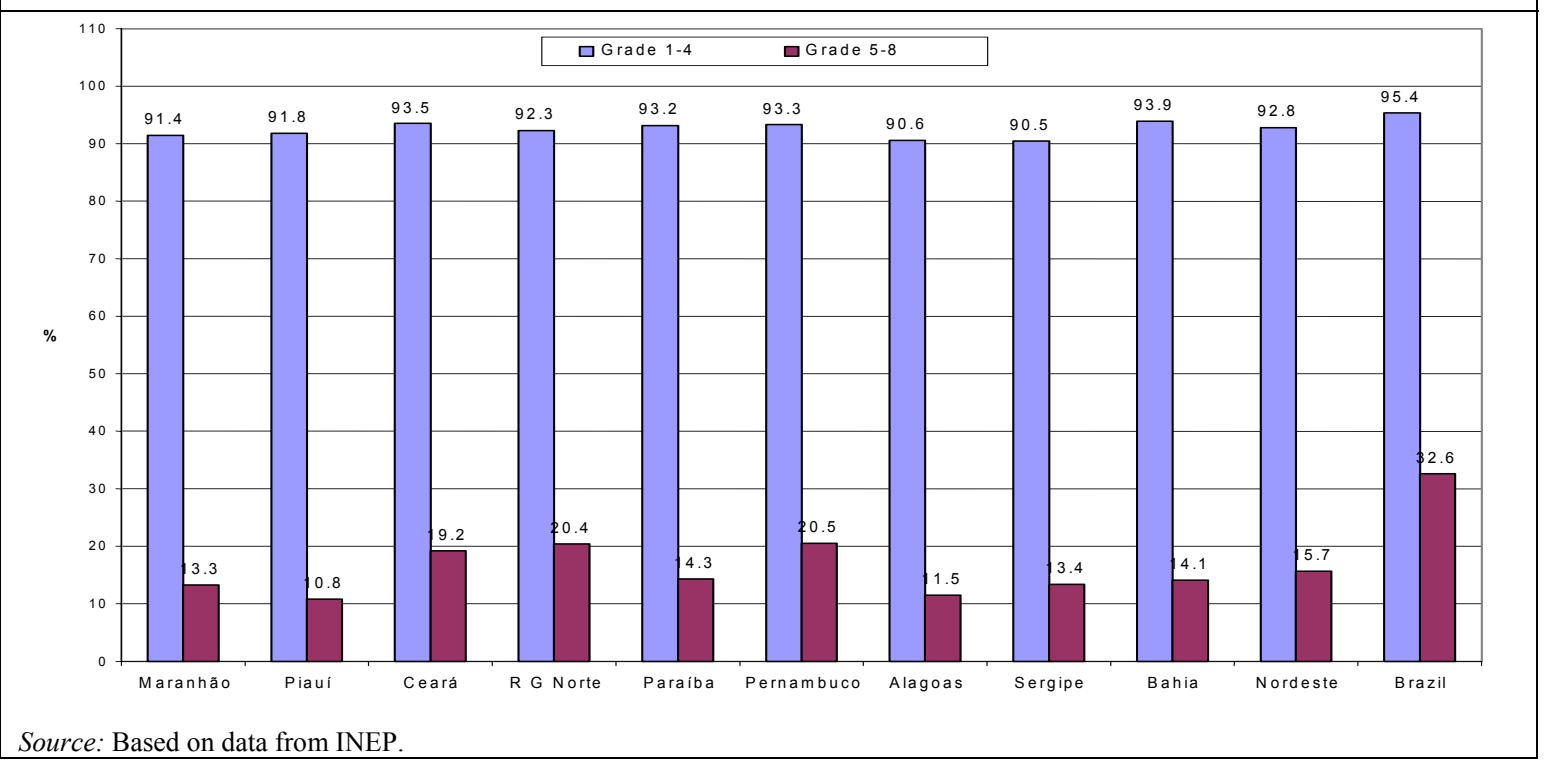

The most equitable way of increasing Brazilian educational attainment would be to focus investment at the fundamental cycle to help more of the poorest children complete $8^{\text {th }}$ grade. International research indicates that at least 8 years of completed education is necessary for the workforce to be global competitive. Hence, Brazil needs more secondary graduates. 


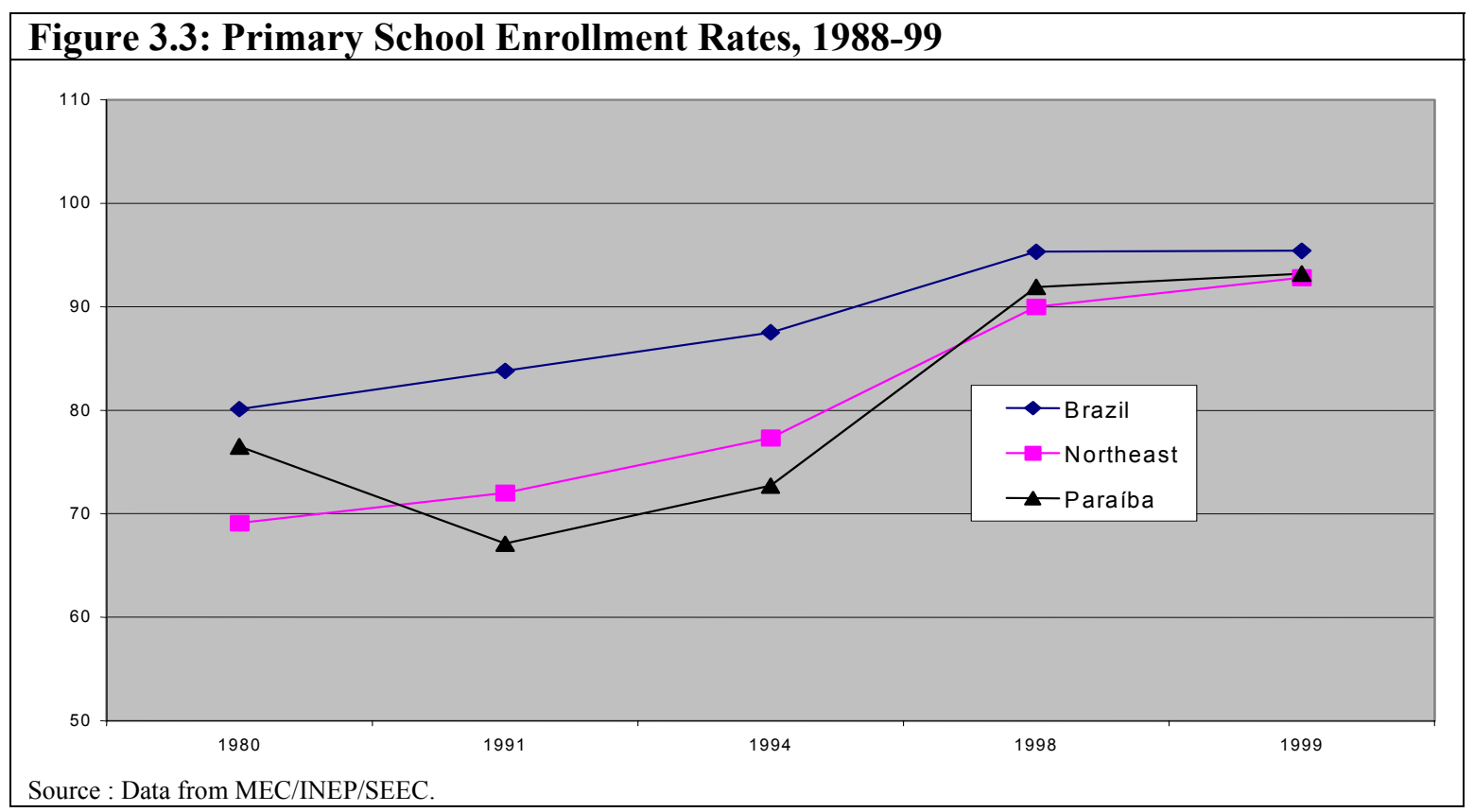

\begin{tabular}{|l|c|c|c|c|}
\hline \multicolumn{1}{|c|}{$\begin{array}{c}\text { Table 3.4: Years of Effective Education, } \\
\text { Total and Indigent Poor Population, } \\
\text { 1981-99 }\end{array}$} \\
\hline & Total & Indig & Total & Indig \\
\hline & 4.46 & 2.19 & 6.41 & 3.78 \\
\hline Brazil & 2.57 & 1.72 & 4.28 & 2.88 \\
\hline Maranhão & 2.43 & 1.56 & 4.14 & 2.78 \\
\hline Piauí & 2.84 & 1.61 & 4.75 & 3.15 \\
\hline Ceara & 3.48 & 1.95 & 5.57 & 3.69 \\
\hline $\begin{array}{l}\text { Rio Grande } \\
\text { do Norte }\end{array}$ & 3.37 & 2.03 & 5.46 & 3.06 \\
\hline Paraíba & 3.47 & 2.05 & 5.36 & 3.46 \\
\hline Pernambuco & 2.61 & 1.6 & 4.67 & 2.83 \\
\hline Alagoas & 3.02 & 1.64 & 5.42 & 3.46 \\
\hline Sergipe & 3.15 & 1.86 & 4.69 & 3.09 \\
\hline Bahia & \multicolumn{3}{l}{} \\
\hline $\begin{array}{l}\text { Indig: Below indigence poverty line. } \\
\text { Note: Effective education evaluated as years of completed education. } \\
\text { Source: Calculations based on PNADs 1981 and } 1999 .\end{array}$ \\
\hline
\end{tabular}

School attendance. School attendance of poor students in Paraíba is also increasing. In Paraíba, poor students' (from the bottom 20 percent of the income distribution) school attendance increased from 60 percent in 1981 to more than 90 percent in 1998. As in Brazil as a whole, in Paraíba children from rich households have, on average, a higher school attendance than children from poor households. The enrollment was 99 percent for children from the 20 percent richest households. Furthermore, children from richer households are also less likely to repeat a school year and they complete more years of schooling than children from poor households. 
Data reveal a strong correlation between poverty and educational attainment in the Northeast. The level of education of the extremely poor is the lowest, and it is also increasing more slowly than average. Average years of effective education of the total active population in Brazil increased by almost 2 years, from 4.5 years in 1981 to 6.4 years in 1999. In 1999, average years of effective education of the total population in Paraíba increased by 2.1 years, from 3.4 years in 1981 to 5.5 years in 1999 (Table 3.4). For the indigent poor - with per-capita family income below the indigence poverty lineit increased less, from 2.0 years in 1981 to only 3.1 years in 1999 . This shows that school attainment of the poor is increasing fast, but the gap between the poor and nonpoor in school attainment is not closing.

The recent educational advances have included many poor children in the education system that did not earlier have access. However, educational exclusion increases at higher levels of the education system in Brazil, and more so in Paraiba. While many middle-class students continue to post-secondary education, it is still most unlikely that students from low-income families obtain this opportunity. In fact, the odds are that less than 15 percent of the children that started primary school, raised in families from the lowest 30 percent of the income distribution, will complete primary education, and only 4 percent of these will complete secondary education. The high repetion is the main impedement to expantion of education, access much less so.

\begin{tabular}{|c|c|c|c|}
\hline \multirow[t]{3}{*}{$\begin{array}{l}\text { Table 3.5: } \\
\text { Promotior }\end{array}$} & Repetitiol & and Evasi & on, 1999 \\
\hline & \multicolumn{3}{|c|}{ Grade 1-4 } \\
\hline & $\begin{array}{c}\text { Promotion } \\
\text { Rate }\end{array}$ & $\begin{array}{c}\text { Repetition } \\
\text { rate }\end{array}$ & $\begin{array}{c}\text { Evasion } \\
\text { Rate }\end{array}$ \\
\hline Brazil & 73.6 & 21.6 & 4.8 \\
\hline Northeast & 65.1 & 28.6 & 6.2 \\
\hline \multirow[t]{3}{*}{ Paraíba } & 64.0 & 30.6 & 5.4 \\
\hline & \multicolumn{3}{|c|}{ Grade 4-8 } \\
\hline & $\begin{array}{l}\text { Promotion } \\
\text { Rate }\end{array}$ & $\begin{array}{c}\text { Repetition } \\
\text { rate }\end{array}$ & $\begin{array}{c}\text { Evasion } \\
\text { rate }\end{array}$ \\
\hline Brazil & 74.5 & 18.6 & 6.9 \\
\hline Northeast & 73.7 & 19.9 & 6.4 \\
\hline Paraíba & 74.8 & 19.8 & 5.4 \\
\hline \multicolumn{4}{|c|}{ Source: $\mathrm{MEC/Inep/SEEC.}$} \\
\hline
\end{tabular}

Efficiency. In 1999, at primary level, 30.6 percent of students repeated (compared to 21.6 percent nationally). Of the 4-8 graders 75 percent of the students were promoted, which is in line with Brazil as a whole. Twenty percent repeated and 5 percent left the school system altogether. Thus, the second part of primary school in Paraíba is not very different to Brazil as a whole. The low entry in secondary education is partly explained by the low completion rates of primary school. Finally, it is worth remembering that international experience shows that a student who repeats first grade is at great risk of further repetition and eventually of dropping-out of the school system altogether. 


\begin{tabular}{|lllllllll|}
\hline \multicolumn{1}{|c|}{ Table 3.6: Percentage of children behind according to age, 1999 } \\
\hline & $\begin{array}{l}\mathbf{7} \\
\text { years } \\
\text { old }\end{array}$ & $\begin{array}{l}\mathbf{8} \\
\text { years } \\
\text { old }\end{array}$ & $\begin{array}{l}\mathbf{9} \\
\text { years } \\
\text { old }\end{array}$ & $\begin{array}{l}\mathbf{1 0} \\
\text { years } \\
\text { old }\end{array}$ & $\begin{array}{l}\mathbf{1 1} \\
\text { years } \\
\text { old }\end{array}$ & $\begin{array}{l}\mathbf{1 2} \\
\text { years } \\
\text { old }\end{array}$ & $\begin{array}{l}\mathbf{1 3} \\
\text { years } \\
\text { old }\end{array}$ & $\begin{array}{l}\mathbf{1 4} \\
\text { years } \\
\text { old }\end{array}$ \\
\hline Paraíba & 34.1 & 57.4 & 71.8 & 73.3 & 79.0 & 88.2 & 83.5 & 88.3 \\
Northeast & 28.7 & 57.0 & 68.1 & 75.4 & 79.3 & 84.8 & 86.3 & 88.9 \\
Brazil & 19.5 & 39.9 & 45.3 & 53.5 & 58.9 & 67.7 & 69.9 & 75.8 \\
\hline
\end{tabular}

Age-grade distortion. Another serious problem in Brazil compared to other countries is the age-grade distortion. Although Paraíba is not the worst in the Northeast, it is far worse than the Northeast and national average. Thirty-four percent of the 7-year-olds in Paraíba are not in the appropriate grade, but for 10-year-olds the figure increases to 73.3 percent, compared to 53.5 percent for Brazil as a whole, and for 14-year-olds it is 88 percent, compared to 76 percent for Brazil as a whole (Table 3.6). Finally, the promotion rate, which measures the number of students who pass from one grade to the next, was 64 percent in Paraíba for grade 1-4 in 1999, 1 percentage points lower than the national average of 74 percent (Table 3.5). Moreover, the age-grade distortion is exacerbated in rural areas. Hence, over-aged primary school students are a key challenge for the education system.

\begin{tabular}{|c|c|c|c|c|c|c|c|c|c|}
\hline & & & & Iraíba & & & & & \\
\hline & & Total & & & Public & & & Private & \\
\hline & Total & Male & Female & Total & Male & Female & Total & Male & Female \\
\hline Primary & 16 & 16 & 16 & 17 & 17 & 17 & 15 & 15 & 14 \\
\hline Secondary & 19 & 19 & 19 & 20 & 20 & 20 & 18 & 18 & 18 \\
\hline & & & & rtheast & & & & & \\
\hline & & Total & & & Public & & & Private & \\
\hline & Total & Male & Female & Total & Male & Female & Total & Male & Female \\
\hline Primary & 16 & 17 & 16 & 17 & 17 & 17 & 15 & 15 & 14 \\
\hline Secondary & 20 & 19 & 20 & 20 & 20 & 20 & 18 & 18 & 18 \\
\hline & & & & razil & & & & & \\
\hline & & Total & & & Public & & & Private & \\
\hline & Total & Male & Female & Total & Male & Female & Total & Male & Female \\
\hline Primary & 15 & 15 & 15 & 16 & 16 & 15 & 14 & 14 & 14 \\
\hline Secondary & 19 & 19 & 19 & 19 & 19 & 19 & 18 & 18 & 18 \\
\hline
\end{tabular}

Graduation. Students graduate later in Paraíba and the Northeast, than in the nation. In Paraíba and the Northeast, students are on average one year older when graduating from primary school than in Brazil as a whole (Table 3.7). The average graduation age for primary and secondary education is high in public schools (17 and 20 years of age respectively) and two years higher than in private schools. 
Results. Despite national curriculum parameters and assessment and the guaranteed provision of text books, improvements in classroom teaching remain a major challenge. Results on the National Education Evaluation System (SAEB) tests have shown that children from Brazil and Paraíba are learning less than what is expected.

\begin{tabular}{|c|c|c|c|}
\hline \multicolumn{4}{|c|}{$\begin{array}{l}\text { Table 3.8: Average Student Achievement Scores } \\
\text { grades } 4 \text { and } 8,1995-99\end{array}$} \\
\hline & 1995 & 1997 & 1999 \\
\hline \multicolumn{4}{|c|}{ Grade 4 - Portuguese } \\
\hline Paraíba & 178 & 179 & 168 \\
\hline Northeast & 178 & 178 & 157 \\
\hline Brazil & 188 & 186 & 171 \\
\hline \multicolumn{4}{|c|}{ Grade 4 - Mathematics } \\
\hline Paraíba & 179 & 182 & 175 \\
\hline Northeast & 179 & 181 & 169 \\
\hline Brazil & 191 & 191 & 181 \\
\hline \multicolumn{4}{|c|}{ Grade 8 - Portuguese } \\
\hline Paraíba & 237 & 240 & 225 \\
\hline Northeast & 230 & 241 & 225 \\
\hline Brazil & 256 & 250 & 233 \\
\hline \multicolumn{4}{|c|}{ Grade 8 - Mathematics } \\
\hline Paraíba & 238 & 238 & 236 \\
\hline Northeast & 232 & 240 & 236 \\
\hline Brazil & 253 & 250 & 246 \\
\hline
\end{tabular}

SAEB test scores are available in Mathematics and Portuguese Language for the $3^{\text {rd }}, 4^{\text {th }}$, and $8^{\text {th }}$ grades. These scores show that performance by $4^{\text {th }}$ graders in Paraíba is comparable the other states of the Northeast, though substantially below the rest of Brazil (Table 3.8). The results show that scores on the whole are going down rather than improving (Table 3.8). However, there may exist a problem of comparability of the 1999 results with the results from previous years because both public and private schools obtained lower test scores in Brazil as a whole and its states including Paraíba. One reason may be large inflow of new students from the lowest income groups. This could have reduced achievement since many of these children were and maybe still are malnourished, which reduce their cognitive skills.

The good news for Paraíba is that the achievement trend (Table 3.9) increased in the 1990s. During 1995-97, the percent increase in Mathematics and Portuguese scores for the $4^{\text {th }}$ grade have been improving more than the average in the Northeast and Brazil as a whole. Also, during 1997-99 the scores in both Mathematics and Portuguese deteriorated less in Paraíba than in the Northeast and Brazil for $4^{\text {th }}$ and $8^{\text {th }}$ grade of primary school and $3^{\text {rd }}$ year of secondary school. 


\begin{tabular}{|l|c|c|c|c|}
\hline \multirow{2}{*}{ Table 3.9: Variation in Test Scores, 1995/97 and 1997/99 } \\
\hline \multirow{3}{*}{ Region } & \multicolumn{2}{|c|}{$\begin{array}{c}\text { Change } \\
\text { 1995-97 }\end{array}$} & \multicolumn{2}{c|}{$\begin{array}{c}\text { Change } \\
\text { 1997-99 }\end{array}$} \\
\cline { 2 - 5 } & $\begin{array}{c}\text { Portuguese } \\
\text { (percent) }\end{array}$ & $\begin{array}{c}\text { Mathematics } \\
\text { (percent) }\end{array}$ & $\begin{array}{c}\text { Portuguese } \\
\text { (percent) }\end{array}$ & $\begin{array}{c}\text { Mathematics } \\
\text { (percent) }\end{array}$ \\
\hline Paraíba & 0.7 & 1.8 & -6.2 & -4.2 \\
Northeast & -0.1 & 0.9 & -11.4 & -6.7 \\
Brazil & -0.9 & 0.1 & -8.4 & -5.1 \\
Paraíba & 1.3 & 0.1 & -6.2 & -1.0 \\
Northeast & 4.4 & 3.3 & -6.7 & -1.7 \\
Brazil & -2.4 & -1.3 & -6.8 & -1.5 \\
& & & & -2.0 \\
Paraíba & -0.1 & 5.9 & -3.3 & -8.5 \\
Northeast & 3.8 & 11.0 & -8.3 & -2.9 \\
Brazil & -2.1 & 2.4 & -6.1 & \\
\hline
\end{tabular}

Parent's education. Research has shown that parent's education is an important quality factor in a child's education and more so the education of the mother than the father, even after controlling for differences in income levels. Since the large majority of poor children have parents that completed very little formal education, the poor children are at much greater risk of not completing any level of education themselves, for example due to lack of support at home. Research reveals the returns to education are positive and increasing with level of completed education in Brazil. Moreover, for tertiary education they continue raising very rapidly (for example, Blom and Verner 2001). Hence, children from poor families need special support such as tutoring in order not to be left behind children from poor families.

Teachers. While the quality of education as reflected in test scores, repitition rates, agegrade distortion, school attainment, and functional literacy leaves much to be desired, the dedication of the teachers were found to be generally good, though the teachers did not always make the best use of school time (Box 3.1). Improving the quality of education in Paraiba's decentralized system requires addressing the shortage of teachers skills and lack of formal division between state and municipal functions and removing political influence over staff appointments.

The quality of Paraíba's teachers, as measured by their own education level varies highly as well as in Brazil as a whole. For example 6 and 3 percent respectively, of the teachers at primary level had themselves been educated below secondary level in 2000. However, it is impressive that 43 percent of the teachers in Paraíba have completed higher education, given the state's level of economic development, and it is 26 percentage points higher than in the Northeast as a whole ( 28 percent) and only 6 percentage points lower than the national average of 49 percent. This is particularly impressive given that the difference between teachers' salary of these that have completed primary only and those that hold a masters degree is only R $\$ 25$ in 2000 . 
School facilities. The availability of school facilities is linked to access. In Paraíba, there are 6,922 primary and 395 secondary schools, whereof 91 percent and 68 percent respectively are public schools. The majority of primary schools are located in rural areas (68 percent) while the majority of secondary schools are located in urban areas (99 percent). This indicates that access to primary school is far more equal than access to secondary school. The number of primary and secondary schools per student are slightly above the average in Brazil.

School quality. School quality inputs can have a positive impact on student learning. In Brazil and its states school inputs and characteristics do not have nearly as much impact on learning achievement levels, as do the other previous mentioned background variables. State and municipal governments have not managed to guarentee that all their schools meet minimum standards for materials, furniture infrastructure and instructional time. Data on facilities reveal that less than half of all primary school facilities have a library (36 percent), 27 percent have sports facilities, and 8 percent have a science lab. At the secondary level, facilities appear to be much better than at the primary level, 80 percent have a library, 58 percent have sports facilities, and 25 percent have a science lab. These numbers, however, are substantially below those in other states and poor students are disproportionately more likely to be enrolled in schools lacking quality inputs. Because children attend schools that reflect residental income patterns, substandard schools are generally attended by poor children, continuing the cycle of inequality and poverty (World Bank 2002). One solution would be to channeling additional resources and technical assistance to under-performing schools.

Early childhood development is also an area that could be expanded. This may prove important for improving results of particularly the poor children. Many poor children, particularly in the rural Northeast where drought are recurrent, are undernourished and many also suffer from ill health. The cognitive skills of children are most often underdeveloped when a child does not obtain the daily needed caloric intake, including sufficient protein and micronutrients. Programs in Brazil as a whole disproportionately serve children who are older and from better-educated families. Additionally, urban areas and richer families receive a disproportionate-large share. Introducing early childhood development programs could turn out to be an important investment in Paraíba's future. 


\section{Box 3.1: Evidence on Education from School Visits in the Northeast}

Physically, most schools are in good condition in the Northeast. ${ }^{9}$ The states have invested a lot in schools and most are attractive and clean, with the necessary space for materials and assemblies. The Northeast has fulfilled the prerequisite of having an attractive and physical environment that is conducive to learning. Textbooks and instructional materials were present in most, but not all, schools. The large schools had books and audiovisual equipment, but some rural schools did not have enough. There have been some innovative measures to improve learning. These include accelerated classes and adult literacy for parents. However, they do not exist in most schools, and many students and parents who could benefit do not have access to them. Teachers and principals have received much training, and most teachers are qualified to teach. The teachers in the schools visited were dedicated, well-meaning, and diligent in their duties, as they understood them. They had planned their lessons, and they had spent time writing material on the board. However, in the schools observed, the teachers still do not use class time efficiently, and learning is quite deficient.

The following problems were observed in schools: (1) larger periurban schools had many audiovisual materials that are underused; (2) much of the class time in the schools visited was spent copying from the blackboard; (3) books are generally available, but they were not used when there was clearly a need (for example to read and discuss a text rather than copy it.); (4) possibly as a result of these practices, students cover little material in classes; (5) many classes of even good schools stop 5 to 10 minutes before the break; (6) teachers were often engaged with one or two students, while the others were unoccupied and running around, and (7) children in $4^{\text {th }}$ grade cannot read. International research shows that once students fall behind in grade 1, they may not catch up and that boys are particularly vulnerable to low-quality instruction ${ }^{10}$. Research also shows that class size does not make a difference, but the teacher's general education does, and that the home environment accounts for only 10 percent of reading achievement variance. The other 90 percent is due to poor instruction, which the government can help improve. The policy recommendation here is to undertake a statewide campaign to economize time, with slogans such as "make every minute count." One of its objectives could be to enable nearly all students to read fluently by the end of grade 1 .

Source: World Bank school visits in the Northeast, February 2002.

\subsection{Educational Financing, Policies, and Programs}

The progress made in recent decades has been due to increased resources devoted to education, increased priority placed towards primary education, increased responsibility given to municipalities for education delivery, and by a number of federally-funded programs. At present, about half the public funding for education is provided by the state, about 30 percent by municipalities, and the balance 20 percent by the federal government, usually through programs implemented by municipalities.

Brazil has a complex system of allocating public funds to education. The Constitution requires that the federal government spend at least 18 percent of its tax revenues on education and that the states spend at least 25 percent of their tax revenues, including the proceeds from intergovernmental transfers. Of these resources, 60 percent must go exclusively to primary education. In addition, the Constitution provides for earmarking of

\footnotetext{
${ }^{9}$ These conclusions were based on schools visits in Rio Grande do Norte, Ceará, and Bahia.

${ }^{10}$ Fuller, Dellagnelo, and Strath 1999.
} 
a wage tax (the salário educação, 2.5 percent of wages) for expenditures on primary education. The tax is collected by the Fundo Nacional de Desenvolvimento da Educação (FNDE), with one third distributed to the federal programs to attain universal access to primary education and two thirds distributed to state secretaries of education (prorated according to tax collection amounts).

In 1996 a law was passed to clarify the roles and responsibilities of each sector of government involved in the provision of education (federal, state, and municipal) and to create the Fund for the Maintenance and Development of Primary Education and Enhancement of the Teaching Profession (FUNDEF) (see Box 3.2). The law provides a greater role to municipalities for primary education, while leaving the responsibility of secondary education with the state. The federal government has a plethora of programs in education aimed at improving the coverage and quality of education, particularly primary education. These are described below (from World Bank 2002a):

School Development: Fundo de Fortalecimento da Escola (FUNDESCOLA), a $\mathrm{R} \$ 1.3$ billion fund (with World Bank financing) aims to improve access, attendance, quality, and the administration of primary education in several municipalities in the North, the Northeast, and the Center-West. The program aims to provide schools and parent associations with more control over financial resources; make sure that schools meet minimum operation standards with regard to teacher qualification, pedagogical inputs, and equipment and physical conditions; design and implement school development plans; implement school improvement projects, which comprise actions and measurable learning improvement targets; and develop, test, and disseminate various pedagogical and organizational frameworks that could improve learning. The fund finances inputs, development plans, and technical assistance to primary schools.

Direct Financing of Schools. The Direct Cash at Schools Program (Programa Dinheiro Direto Na Escola) provides money to meet basic school needs. Schools with more than 100 students that have an established managing unit (a PTA at public schools or an NGO) and a bank account are eligible for this program, which transfers cash directly to the school for use by the managing unit on the basis of the number of students. The program is funded by the National Education Development Fund (Fundo Nacional de Desenvolvimento da Educação, FNDE), which is an autonomous department with the goal of getting financial resources in order to finance educational projects.

Teacher Training. The government's Teacher Training Program (Programa de Formação de Professores em Exercício, PROFORMAÇÃO) is targeted to the North, Northeast, and Center-West. It is financed by FUNDESCOLA and implemented through the Government's Distance Education Program, both computer based (Programa Nacional de Informática na Educação, PROINFO) and TV-based (TV-Escola).

Curricular Benchmarks The Parâmetros Curriculares Nacionais comprises development and training with respect to six flexible modules of curricula covering preschool, reading and writing, the first four years of formal schooling, 
years 5 to 8 of formal schooling, young and adult education, and education for indigenous populations.

Textbooks. Includes a continuous assessment of existing textbooks (Avaliação do Livro Didático) for the first four-year series of the primary education cycle and a program (Programa Nacional do Livro Didático, PNLD) of free distribution of primary education textbooks for Portuguese, mathematics, science, social studies, history, and geography.

Libraries. The National School Library Program (Programa Nacional Biblioteca da Escola, PNBE), introduced in 1997, distributes reference and literature books to schools, with complementary teaching and library administration materials. A total of 8 million books have been distributed to 56,000 schools.

Evaluation of Results. Sistema Nacional de Avaliação da Educação Básica (SAEB) evaluates educational outcomes at the end of the schooling cycles $\left(4^{\text {th }}\right.$, $8^{\text {th }}$, and $11^{\text {th }}$ years). Surveys for 1995,1997 , and 1999 have been completed.

Eradication of Child Labor. The primarily rural Programa de Erradicação do Trabalho Infantil (PETI), managed by the Social Security and Social Assistance Ministries, provides transfers to local schools per child in the program, and income to selected poor families (Bolsa Criança Cidadã). The program is aimed at families with an income below one half the minimum wage with children of school age (7 to 14$)$.

Student Health. The Student Health National Program focuses on ensuring good sight and hearing. It includes a sight rehabilitation campaign (Olho no Olho and Quem Ouve Bem, Aprende Melhor!), distribution of training and evaluation materials, medical treatment to students with sight problems, and distribution of glasses and hearing aids. The programs are funded with FNDE and Ministry of Health resources.

Student Nutrition. Introduced in 1955, the well-known school lunch program merenda escolar (or Programa Nacional de Alimentação Escolar) is aimed at providing 15 percent of students' daily caloric and protein needs. It is funded by FNDE.

Student Transportation. FNDE finances municipal acquisition of vehicles for transporting students that live far away from schools.

Education Statistics. A national school census is conducted every year. It comprises three surveys - of school education, university education, and education financing. In addition, a census of teachers was conducted in 1997.

Secondary Education. Benefits from federal programs to improve access and quality, including the School for Youth Project (Projeto Escola Jovem), which seeks improvements in curricula, teacher training, libraries, and laboratories, distance education, expansion of capacity, and administration of school systems. The project is financed by the IDB with cofinancing from the federal and state 
governments. Distance education for teachers is also available through TV-Escola. A specialized test for secondary education (Exame Nacional do Ensino Médio, ENEM) was introduced in 1998. This is in addition to the SAEB test, which covers all basic education including secondary education.

\begin{abstract}
Box 3.2: Basic Education Development and Teachers' Incentive Fund
Both states and municipalities operate primary schools in Brazil. While states tend to provide schools in larger urban areas (except Rio de Janeiro), municipalities are often responsible for primary schooling in poorer, rural areas. The Fundo de Manutenção e Desenvolvimento do Ensino Fundamental e de Valorização de Magistério (Basic Education Development and Teachers' Incentive Fund or FUNDEF) is designed to address disparities in education spending by requiring states to pool resources with their respective municipalities to ensure a minimum level of spending per pupil in all primary schools.

Under the FUNDEF law, each state government must assign 15 percent of its two principal revenue sources - the Imposto Sobre Operações Relativas a Circulação de Mercadorias e sobre Prestações de Serviços de Transporte Interestadual, Intermunicipal e de Comunicação (Tax on the Circulation of Goods, on Interstate and Intermunicipal Transportation Services, and on Communication Services, ICMS) and the Fundo de Participação dos Estados (State Revenue Sharing Fund, FPE) - to a FUNDEF account. The municipalities within the state must contribute 25 percent of their principal transfer revenues (a share of the state ICMS and a municipal participation fund). If the sum of the state and municipal contributions, divided by the number of primary school students, is less than a standard amount, the federal government is required to finance the difference. The total amount of FUNDEF funds (including the state and municipal contributions) is distributed among the state and its municipalities on the basis of enrollment. Thus a state with a high proportion of students in municipal schools may contribute more to FUNDEF than it receives back. A state with a high proportion of primary school students in state schools would receive more back than it pays in.
\end{abstract}

The financing of public education in Brazil is shared between federal, state, and municipal governments. While public educational spending (4.7 percent of GDP) exceeds the average of Latin America (3.7 percent of GDP), it is characterized by inequities and inefficiencies. One example is higher education where enrollments represent 2 percent of enrollments. However higher-education expenditure amounts to 25 percent of total education expenditures. Moreover, the poorest 30 percent of the population generally do not enroll beyond the primary school.

The estimated average per-student expenditure in Brazil was US\$ 494.51 in 1998 dollars. Brazil appears at first glance to spend little per-student in comparison with other countries. However, such comparisons do not factor in the actual costs of producing a graduate. Once spending on repetition and dropout is taken into account, Brazil's perstudent expenditure levels reach US\$1,020 comparable to Argentina and Malaysia. Therefore, current resources could be better spent in Brazil. 


\begin{tabular}{|c|c|c|}
\hline \multicolumn{3}{|c|}{$\begin{array}{l}\text { Table 3.10: State Spending on } \\
\text { Education, } 1995 \text { and } 1999 \\
\text { (percentage of GDP) }\end{array}$} \\
\hline & 1995 & 1999 \\
\hline Alagoas & 3.4 & 3.6 \\
\hline Bahia & 2.6 & 3.3 \\
\hline Ceará & 2.7 & 3.2 \\
\hline Maranhão & 5.0 & 4.5 \\
\hline Paraíba & 3.4 & 5.3 \\
\hline Pernambuco & 1.8 & 2.0 \\
\hline Piauí & 4.8 & 5.9 \\
\hline Rio Grande do Norte & 3.4 & 5.4 \\
\hline Sergipe & 4.1 & 4.1 \\
\hline
\end{tabular}

The state government has shown its commitment to improving education in Paraíba. Education spending there has been steadily increasing and so has its share of GDP (Table 3.10). Education's share of total GDP increased 1.9 percentage points to 5.3 percent during 1995-99. In 2000 Paraíba spent R \$459 million on education, which was 24 percent of total spending that year (Table 3.11). During 1995-2000, the annual educational spending grew in real terms 11.3 percent, nearly the double of the national average (of this amount, 70 percent was allocated to basic education, 6.2 percent to secondary education, 3.4 percent to higher education, 1.7 percent to special education, and 0.2 percent to preschool).

Table 3.11: Education Expenditures, Shares of Total, and Growth

\begin{tabular}{|l|c|c|c|c|c|}
\hline & \multicolumn{2}{|c|}{$\begin{array}{c}\text { Expenditures } \\
\text { (thousands of R\$) }\end{array}$} & \multicolumn{2}{c|}{$\begin{array}{c}\text { Educational Share of } \\
\text { Total Expenditures }\end{array}$} & $\begin{array}{c}\text { Annual Growth Rate } \\
\text { (percent) }\end{array}$ \\
\cline { 2 - 5 } & $\mathbf{1 9 9 5}$ & $\mathbf{2 0 0 0}$ & $\mathbf{1 9 9 5}$ & $\mathbf{2 0 0 0}$ & \\
\hline Alagoas & 203,156 & 260,971 & 0.20 & 0.17 & 5.14 \\
\hline Bahía & $1,020,096$ & $1,318,855$ & 0.17 & 0.21 & 5.27 \\
\hline Ceará & 509,919 & 763,584 & 0.17 & 0.19 & 8.41 \\
\hline Maranhão & 380,867 & 301,164 & 0.25 & 0.14 & -4.59 \\
\hline Paraíba & 268,948 & 459,271 & 0.20 & 0.24 & 11.30 \\
\hline Pernambuco & 471,100 & $1,357,138$ & 0.15 & 0.14 & 23.57 \\
\hline Piauí & 226,797 & 413,795 & 0.18 & 0.09 & 12.78 \\
\hline Rio Grande do Norte & 242,301 & 471,626 & 0.19 & 0.24 & 14.25 \\
\hline Brazil & $21,423,146$ & $27,962,191$ & 0.17 & 0.18 & 5.47 \\
\hline
\end{tabular}




\begin{tabular}{|c|c|c|c|c|}
\hline Table 3.12: Educati & n Spe & ndin & 199 & \\
\hline $\begin{array}{l}\text { Average Spe } \\
\text { Preschool, Primary, }\end{array}$ & $\begin{array}{l}\operatorname{ding} P \\
\text { condar } \\
\text { (RS) }\end{array}$ & $y$, an & Tertic & levels \\
\hline & Pre. & Pri. & Sec. & Ter. \\
\hline Alagoas & 396 & 350 & 1058 & 9423 \\
\hline Bahia & 438 & 322 & 395 & 6939 \\
\hline Ceará & 323 & 361 & 543 & 6649 \\
\hline Maranhão & 324 & 319 & 546 & 8040 \\
\hline Paraíba & 454 & 354 & 731 & 6995 \\
\hline Pernambuco & 450 & 376 & 557 & 3917 \\
\hline Rio Grande do Norte & 369 & 381 & 646 & 14288 \\
\hline
\end{tabular}

Total educational spending in Paraíba as elsewhere in Brazil is biased toward higher education. In 1997, spending per student was only R $\$ 454$ at the preschool level, $R \$ 354$ at the primary level (less than a quarter of what was spent in the Federal District), R\$731 at the secondary level (around the median for state spending), and R $\$ 6,995$ at the tertiary level (Table 3.12). This indicates a distortion in spending, biased toward the higher levels of education and regressive in nature, because far more students from the top income quintiles attend secondary and tertiary education than students from lower-income quintiles.

While data on the incidence of spending are not available, the high number of children in poverty, relatively high enrollment rates in the state and the fact that 70 percent of spending goes toward primary education would indicate that expenditures on primary education are progressive. Contrary to this progressive spending pattern is the high percapita spending on tertiary education where few poor attend and hence tertiary spending is more regressive in nature.

Efforts to improve equity in the education system in Brazil are likely to pay dividends in social as well as in human capital. Fundef has been a turning point for the Northeast and its states and poor municipalities have gained substantial educational resources. At the municipal level, data on expenditures are not available, but it is possible to use proxies to spending - per-capita numbers of schools. It is also possible to compare this information with living standards at the municipal level as measured by the Human Development Index (HDI) with the aim of determining if education spending is pro-poor. ${ }^{11}$ Table 3.13 presents a sample of municipalities with a range of HDI rankings.

\footnotetext{
${ }^{11}$ The HDI is a composite index containing 9 indicators of socio-economic well being related to education, health, water supply, electricity, telecommunications, vehicles, dependency ratios, and agricultural production.
} 


\begin{tabular}{|c|c|c|c|c|c|c|}
\hline \multicolumn{7}{|c|}{ Table 3.13: Ranking of selected municipalities, Welfare index, and Schools } \\
\hline \multirow[t]{2}{*}{ Quintile } & \multirow[t]{2}{*}{ Municipality } & \multirow[b]{2}{*}{$\begin{array}{l}\text { Population } \\
2000\end{array}$} & \multirow[b]{2}{*}{ HDI } & \multicolumn{3}{|c|}{ Rankings } \\
\hline & & & & $\begin{array}{c}\text { HDI } \\
\text { (1 is highest } \\
170 \text { lowest) }\end{array}$ & $\begin{array}{c}\text { Total } \\
\text { schools** }\end{array}$ & $\begin{array}{c}\text { Schools } \\
\text { per capita }\end{array}$ \\
\hline \multirow[t]{5}{*}{$1^{\text {st }}$, top 5} & João Pessoa & $\mathbf{5 9 7 , 9 3 4}$ & 0.767 & 1 & 1 & 167 \\
\hline & Campina Grande & 355,331 & 0.618 & 2 & 2 & 164 \\
\hline & Cabedelo & 42,832 & 0.591 & 3 & 60 & 168 \\
\hline & Patos & 91,761 & 0.534 & 4 & 3 & 159 \\
\hline & Cajazeiras & 54,715 & 0.521 & 5 & 5 & 149 \\
\hline \multirow[t]{5}{*}{$2^{\text {nd }}$, top 5} & Jericó & 7,416 & 0.402 & 43 & 97 & 63 \\
\hline & Queimadas & 36,032 & 0.402 & 44 & 7 & 112 \\
\hline & Pedras de Fogo & 25,861 & 0.400 & 45 & 49 & 155 \\
\hline & Frei Martinho & 2,923 & 0.399 & 46 & 147 & 28 \\
\hline & Pedra Branca & 3,692 & 0.399 & 47 & 125 & 17 \\
\hline \multirow[t]{5}{*}{$3^{\text {rd }}$, top 5} & Lagoa & 4,844 & 0.377 & 85 & 96 & 78 \\
\hline & Lucena & 9,755 & 0.377 & 86 & 133 & 146 \\
\hline & Borborema & 4,730 & 0.375 & 87 & 159 & 133 \\
\hline & Prata & 3,425 & 0.375 & 88 & 167 & 123 \\
\hline & São José do Bonfim & 2,838 & 0.375 & 89 & 170 & 117 \\
\hline \multirow[t]{5}{*}{$4^{\text {th }}$, top 5} & Mogeiro & 13,231 & 0.350 & 127 & 69 & 105 \\
\hline & Cuité & 19,946 & 0.348 & 128 & 20 & 96 \\
\hline & Montadas & 3,969 & 0.348 & 129 & 160 & 113 \\
\hline & Santana dos Garrotes & 7,882 & 0.348 & 130 & 84 & 47 \\
\hline & Alagoinha & 11,833 & 0.346 & 131 & 100 & 134 \\
\hline \multirow[t]{5}{*}{$5^{\text {th }}$ bottom 5} & Aroeiras & 19,520 & 0.301 & 166 & 6 & 30 \\
\hline & São João do Tigre & 4,481 & 0.299 & 167 & 126 & 38 \\
\hline & Salgadinho & 2,823 & 0.298 & 168 & 151 & 33 \\
\hline & São Miguel de Taipu & 6,086 & 0.297 & 169 & 149 & 126 \\
\hline & Passagem & 1,979 & 0.295 & 170 & 166 & 43 \\
\hline \multicolumn{7}{|c|}{ Source: Census 2000, Atlas do Desenvolvimento Humano, Education Census 2001.} \\
\hline \multicolumn{7}{|c|}{$\begin{array}{l}\text { * IDH municipal, calculated based on the } 1991 \text { census and the } 170 \text { municipalities that existed in Paraiba in } 1991 . \\
\text { ** Include all types of schools (crèches, literacy, primary, and secondary). }\end{array}$} \\
\hline
\end{tabular}

There does not appear to be a clear pattern in the distribution of expenditures as measured by the per-capita number of teachers, schools, or classrooms. For example, Salgadinho, São Miguel de Taipu, and Passagem, the municipalities with the lowest HDI, do not appear to get more resources. Spending does not appear to be definitively regressive or progressive, with the exception of a regressive spending pattern for João Pessoa, which receives more resources. Spearman rank order correlations confirm that none of the correlations between the HDI and expenditure proxies show a significant association.

\section{Education and Poverty}

Many of the poverty-reducing assets discussed above, such as education, experience, and labor market association, are important correlates of poverty and the dynamics thereof. This section takes the analysis a step further and investigates the marginal impact of each individual attribute on the likelihood of a household falling below the indigence poverty 
line in Paraíba, taking into account other characteristics. The analysis reveals (a) a conditional correlation between poverty and characteristics of household heads and (b) information about groups that are particularly vulnerable in 1999. The probability of a household being poor is analyzed based on relevant individual and household characteristics. ${ }^{12}$ One of the salient findings is that poverty can be attributed to the lack of income-generating assets, particularly human capital.

Other poverty studies for Brazil as a whole, such as Ferreira, Lanjouw, and Neri (1998), show that in 1996 education was the central personal attribute determining the likelihood that a household would experience poverty. Other factors such as age, family size, race, and rural living are also important in determining the likelihood of poverty. The findings on Paraíba presented in this section are very much in line with those of Ferreira, Lanjouw, and Neri. A discussion of some of the variables explaining poverty follows below.

This section analyzes the impact of the different levels of education on the likelihood of being poor for Paraíba and the Northeast region. The status of the household-poor or non-poor-is regressed on relevant individual and household characteristics using the probit regression technique. To minimize the likelihood of findings being affected by small sample biases, data for the whole Northeast region is used in the analysis. Given the way the regression model is specified, findings reveal when impacts for Paraíba are different from the region as a whole. Findings presented in Table 4.1, show that Paraíba is not statistically very different from the Northeast as a whole. In the following, it will explicitly be mentioned when differences are encountered.

Education. All levels of education from primary to tertiary are strongly significant and negatively associated with the probability of being poor (Table 4.1). That is, the more education attained the less likely it is that the person will fall below the poverty line. The impact of having completed grade 1-4 of primary education on the likelihood of being poor is the lowest. For completed high school education, the estimated impact is much larger (4 times) than that of primary education. Furthermore, completed tertiary education reduces poverty more than completed secondary education. The likelihood of falling below the poverty line is 6 times lower when having completed tertiary school than having completed grade $1-4$ of primary education.

\footnotetext{
${ }^{12}$ For a detailed analysis of the probit analyses for Northeast Brazil, including Paraíba, see Fiess and Verner (2001).
} 


\begin{tabular}{|c|c|c|c|c|c|c|c|}
\hline able 4.1: Probability of Falling in & 199 & 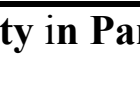 & 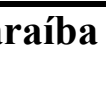 & 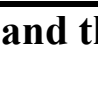 & 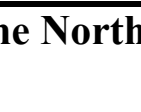 & & \\
\hline Log likelihood $=-4600.6214$ & & $\begin{array}{l}\text { Jumber of } \\
\text { R chi2( } 41 \\
\text { rob }>\text { chi2 } \\
\text { seudo R2 }\end{array}$ & $\begin{array}{l}\text { fobs }= \\
\begin{array}{l}\text { 1) } \\
=47 \\
2=0.0 \\
=0.3\end{array}\end{array}$ & $\begin{array}{l}10271 \\
59.70 \\
000 \\
3409\end{array}$ & & & \\
\hline $\mathrm{P} 0$ & $\mathrm{dF} / \mathrm{dx}$ & Std.Err. & $Z$ & $\mathrm{P}>|\mathrm{z}|$ & & {$[95 \%$} & C.I.] \\
\hline Age & -.0281 & .0033 & -8.47 & 0.000 & 36.65 & -.0346 & -.0216 \\
\hline Age 2 & .0002 & .0000 & 6.59 & 0.000 & 1469.92 & .0001 & .0003 \\
\hline Female* & .2153 & .0164 & 13.08 & 0.000 & .2191 & .1830 & .2476 \\
\hline Black* & .0446 & .0249 & 1.81 & 0.070 & .0753 & -.0042 & .0935 \\
\hline Mulatto* & .0713 & .0134 & 5.24 & 0.000 & .6428 & .0449 & .0976 \\
\hline Rural* & .0364 & .0173 & 2.12 & 0.034 & .2138 & .00242 & .0704 \\
\hline Family size & .1734 & .0141 & 12.22 & 0.000 & 3.695 & .1457 & .2010 \\
\hline ze 2 & -.0142 & .0013 & -10.53 & 0.000 & & -.0168 & -.0116 \\
\hline members under & .1833 & .0113 & 16.33 & 0.000 & & .1611 & .2055 \\
\hline Family members betwe & .1348 & .0085 & 15.77 & 0.000 & .9062 & .1179 & .1516 \\
\hline embers o & -.2393 & .0347 & 6.88 & 0.000 & .03 & -.3075 & -.1712 \\
\hline Com & -.0809 & .0158 & -4.98 & 0.0 & & -.1 & -.0497 \\
\hline Con & -.1615 & .0166 & -8.91 & 0.0 & & & -.1288 \\
\hline Com & -.3363 & .0139 & -19.85 & 0.000 & .2626 & -.3 & -.3090 \\
\hline university* & -.4240 & .0069 & -13.67 & 0.000 & .0642 & & -.4103 \\
\hline $\operatorname{card}^{*}$ & -.1910 & .0121 & -15.46 & 0.000 & & -.2 & -.1672 \\
\hline in agriculture* & .1761 & .0304 & 5.85 & 0.000 & & & .2359 \\
\hline Eml & -.0049 & .0231 & -0.21 & 0.831 & .4192 & & .0403 \\
\hline Eml & .0087 & .0249 & 0.35 & 0.726 & & & .0575 \\
\hline the $p$ & -.0310 & .0378 & -0.81 & 0.419 & & & .0431 \\
\hline $\mathrm{Pa}$ & -.1511 & .2671 & -0.50 & 0.6 & & & .3724 \\
\hline $\mathrm{Pa}$ & .0018 & & 0.13 & 0.8 & & -.0 & .0304 \\
\hline & -.00 & .00 & -0.36 & 0.7 & 3 & & .0002 \\
\hline le * & -.0928 & $.0^{\prime}$ & -1.24 & 0.2 & & -.2 & .0448 \\
\hline$*$ & .0781 & .12 & 0.64 & 0.5 & .0030 & & .3216 \\
\hline to* & .0698 & .06 & 1.14 & 0.252 & .0285 & 19 & .1916 \\
\hline Paraí & .1455 & .0793 & 1.86 & 0.063 & .0179 & -.0100 & .3011 \\
\hline Paraíba Family size & .1504 & .0680 & 2.21 & 0.027 & .2164 & .0171 & 2838 \\
\hline Paraíba Family size_2 & -.0139 & .0060 & -2.29 & 0.022 & .9963 & -.0258 & -.0019 \\
\hline Paraíba Family me & -.0322 & .0501 & -0.64 & 0.52 & .0297 & -.1305 & .0661 \\
\hline Paraíba Family me & -.0263 & .0392 & -0.67 & 0.5 & .0552 & -.1032 & .0505 \\
\hline Paraíl & .02 & .13 & 0.18 & 0.8 & 27 & & .2845 \\
\hline Paraíba Complet & -.0649 & .0 & -0.84 & & & & .0801 \\
\hline Paraíba Com! & -.1170 & .0782 & -1.37 & 0.17 & .0080 & -.2704 & .0363 \\
\hline Paraíba Completed & -.1134 & .0836 & -1.24 & 0.213 & .0101 & -.2772 & .0504 \\
\hline Paraíba Completed & -.0841 & .1953 & -0.41 & 0.68 & .0060 & -.4670 & .2988 \\
\hline a Signed wo & -.0549 & .0603 & -0.88 & 0.378 & .0228 & -.1731 & .0633 \\
\hline Paraíba Employed in a & -.0925 & .1222 & -0.71 & 0.478 & .0115 & -.3321 & .1470 \\
\hline Paraíba Employed in services* & -.0889 & .0992 & -0.84 & 0.398 & .0173 & -.2833 & .1055 \\
\hline Paraíba Employed in industry* & .0584 & .1181 & 0.50 & 0.615 & .0184 & -.1731 & .2900 \\
\hline Paraíba Employed in the public sector* & -.2158 & .1128 & -1.45 & 0.147 & .0021 & -.4369 & .0052 \\
\hline
\end{tabular}

Note: $\quad$ obs. P $\mid .4179729$ pred. P $\mid .3703122$ (at x-bar)

$\left(^{*}\right) \mathrm{dF} / \mathrm{dx}$ is for discrete change of dummy variable from 0 to $1 \quad \mathrm{z}$ and $\mathrm{P}>|\mathrm{z}|$ are the test of the underlying coefficient being 0. Source: Calculations based on PNAD 1999. 
Gender of head of household. Households headed by women are more likely to be poor than those headed by males. Female-headed households have a much larger likelihood of being poor than do male-headed households when other covariates are included in the analysis, such as labor market connection and education (Table 4.1). Hence, social policies favoring women, such as Bolsa Escola where the mother receives the benefit should be strengthened. Furthermore, introducing more kindergarten and childcare facilities for poor mother could facilitate poor women's labor market participation.

Race of head of household. The ethnic background (white, black, mulatto) is another important factor contributing to poverty. The probit regression findings show that mulattos and black Nordestinos have a higher incidence of poverty than their white peers, controlling for other characteristics. Family and education variables capture parts of the difference found in the simple unconditional mean incomes, but still a large part, is due to discrimination or other unexplained individual characteristics of the non-white population group. Policies to assist access to education for poor families are a key to change this picture in the future.

Age of head of household and its members. The older the head of household, the lower probability the household will be poor, albeit at a decreasing rate for the old (Table 4.1). Households with young children are the most poverty prone; households with old people are the least. In Paraíba and the Northeast, families with children younger than 5 appear more likely to be poor than families with no such children. One direct policy intervention would be to facilitate access to childcare. The poor find the shortage of affordable childcare a large obstacle to their daily chores. The gender finding paired with this small children finding indicates that single mothers with small children are far more likely to experience poverty than, for example, male-headed households with no children.

The likelihood of extreme poverty for households with children aged 5 to 15 is lower than for those with children younger than five, but it is still high, and is increasing. The lower likelihood of extreme poverty for households with a member older than 65 may be due to the fact that many of the elderly receive a pension, which would increase household income.

Size of household. Family characteristics, such as household size, are positively correlated with the incidence of poverty. Hence, the larger household the more poverty prone it is. Moreover, larger households are poorer and the effect is concave, indicating that a scaling factor matters for poverty. Finally, the finding for Paraíba is not different to the rest of the Northeast, as large families in Paraíba are not more likely to experience poverty than large households in other states in the Northeast.

Household location. Whether a household was rural or urban was a significant correlate to poverty in 1999 , with rural households more likely to be poor. This is in line with what we observed earlier in the simple statistics. Hence, the deep rural poverty in the Northeast is not due only to lower education achievements and skill levels. The households located in rural Paraíba are more likely to experience poverty than in the rest of the Northeast region. Hence, policy interventions that facilitate poor rural people's access to basic services are key to poverty reduction. Expanding high quality rural education is central to poverty reduction in Paraíba. 


\section{Policy Recommendations on How to Improve Education in Paraíba}

Widespread poverty affects both students' performance and their availability to attend school as their parents compare the cost and benefits of an additional income earner and household support against future gains from additional schooling. These factors demonstrate the effect of a perceived lack of benefit from an education system that is marked by high repetition, high dropout, and low achievement rates. Low levels of education leads to low income, which in turn perpetuates poverty. Policies to improve the quality of education should be the core of the government's poverty reduction strategy. The fact that the poorest 30 percent of Brazilian students have only a 15 percent chance of completing grade four reveals that literacy, achievement, and poverty are highly correlated. Furthermore, low levels of education also affect economic growth through low labor productivity. Hence, education is a key to economic growth and poverty reduction.

Paraíba has made much progress in improving school buildings and equipment and getting the majority of children aged 7-14 in school. The next steps for the government in Paraíba are to increase the education-attainment of the poor; improve the quality of supplied education, including reduction of repetition and school desertion rates; and increase school access for students in rural areas that finish $4^{\text {th }}$ grade.

It is clear that the high illiteracy rates and weak schooling system are problems in Paraíba. Better education will help increase incomes, but it cannot bring an instant reduction in poverty. There has been a rapid expansion of education, but it will take time for the average years of schooling of the workforce to increase. Breaking the intergenerational transmission of poverty requires far-reaching actions in the education sector. Based on the above analysis of the state of education, the following suggestions would help to improve education achievements.

Poor classroom practices are at the core of low educational outcomes. Addressing these requires better teachers and school management. Low content knowledge and poor teaching skills are common among teachers and contribute to low student achievement and high repetition and dropout rates. The management of schools also needs improvement. Paraíba has full-time principals in most schools and some form of incentives may be needed to improve their management of schools. Supply-side policies could channel resources to under-performing schools based on SAEB results.

Students living in rural areas have less access to schools above $4^{\text {th }}$ grade than urban students. Furthermore, they repeat more and drop out earlier than their urban peers. Hence, increased rural focus to close the negative gap between the urban and rural learning and education attainment in Paraíba is needed.

Children from poor households have lower enrollment rates, higher repetition rates, and higher dropout rates than children from nonpoor households. Hence, more assistance to the poor students, such as tutoring, is needed to ensure that they advance as rapidly as the rich students and reach the same level. As girls are now doing better than boys in school, care is needed that boys do not fall behind in Paraíba. 
Poor students' access to levels above primary education and adult basic education need to be strengthened. Universal secondary education can be achieved by targeting resources to primary and secondary schools based on low SAEB scores, reducing repetition, and increasing completion by students in primary education. Where necessary, the number of secondary school places should be expanded. Bolsa Escola could be extended to secondary school, where enrollment gaps between rich and poor are high.

The participation of civil society and families is low. The only participation of parents is in the school councils. Parents can better support their child's education if they are actively involved in the school and maybe even in the classroom. Moreover, promoting more partnership and collaboration in the provision of services from the private sector, the Church, and NGOs may also be a very cost effective way of supplying educational services to the poor and often marginalized populations in Paraíba.

Despite the school lunch programs, hunger and malnourishment continue to be a problem in Paraíba as elsewhere in the Northeast, and a serious impediment to student learning.

Paraíba lags in preschool and early childhool development (ECD) programs. The group of children that has suffered the greatest lack of educational attention is the preschool group. As the legal responsibility for the provision of preschool has shifted to the municipal level, the number of preschool places in the Northeast actually declined (both private and municipal schools) during 1995-2000. Daycare and early childhood education represent a future investment in the human capital of the state, and should be a priority over the long term. Studies have shown that children who have attended preschool perform better academically than those who have not. Programs have been in place to monitor and improve the health outcomes of small children-from early pregnancy through the first years of life. Given the high incidence of poverty and vulnerability among families with children under age 5 , and given the increased economic participation by women, a program of financial transfers linked to early childhood development and education centers (along the lines of the Bolsa Escola and PETI programs) could be influential in reducing poverty. The federal government is currently launching and piloting the Bolsa Alimentação, a program of financial tranfers to the mothers of children age 5 and younger, linked to stringent prenatal, postnatal, and developmental checkups by health professionals. This type of program could be linked to and used as the vehicle for strengthening and expanding early childhood education and care.

Financing for education without creating additional debt obligations is a challenge in Paraíba as elsewhere. One option for financing education could be to reallocate current education expenditures away from tertiary education, in particular away from students from families in, for example, the top 20 percent of the income distribution and direct expenditures to ECD, poor students' access to secondary education.

Finally, there is a need to carry out better monitoring and evaluation of programs. For example students should be evaluated in terms of learning achievement. 


\section{References}

Abreu, Marcelo Paiva de, and Dorte Verner. 1997. "Long-term Brazilian Economic Growth: 1930-94." Paris: Organization for Economic Cooperation and Development.

Blom, Andreas and Carlos Vélez. 2001. "The Dynamics of the Skill-premium in Brazil; Growing Demand and Insufficient Supply?” World Bank, mimio.

Blom, Andreas, Pavcnik, and Norbert Schady. 2001. "Trade Liberalization and Labor Market Adjustment in Brazil," World Bank, mimeo.

Blom, Andreas, Lauritz Holm-Nielsen, and Dorte Verner. 2001. "Education, Earnings, and Inequality in Brazil, 1982-1998: Implications for Education Policy”, World Bank.

Census 2000. *http://www.ibge.gov.br/home/estatistica/populacao/censo2000/.

Currie, Janet. 2001. "Early Childhood Development Programs." Journal of Economic Perspectives, 15 (2): 213-38.

Ferreira, Francisco, Lanjouw, Peter and Marcelo Neri. 1998. "The Urban Poor in Brazil in 1996: A new Poverty Profile Using PPV, PNAD and Census Data". World Bank, mimio.

Fiess, Norbert, and Dorte Verner. 2001. "The Dynamics of Poverty and its Determinants: The Case of Rio Grande do Norte and the Northeast of Brazil." World Bank.

Fuller, B., L. Dellagnelo, and A. Strath. 1999. "How to Raise Children's Early Literacy? The Influence of Family, Teacher, and Classroom in Northeast Brazil." Comparative Education Review, 43 :1-35.

Heckman, James. 1999. "Policies to Foster Human Capital.” Working Paper No. 7288. Cambridge, MA: National Bureau of Economic Research, August.

Rodriguez, Alberto. 2002. "Education in the state of Maranhao: Challenges and Options. World Bank Mimio.

Síntese de Indicadores Sociais. 1999. IBGE (Instituto Brasileiro de Geografia e Estatística)

Tebaldi, Edinaldo, and Dorte Verner. 2002. "Municipal Growth in Rio Grando do Norte, Brazil.” World Bank, mimeo.

World Bank. 2001. “Attacking Brazil’s Poverty”. Washington, D.C. . 2002a. "Growth and Poverty Reduction in Pernambuco." Washington, D.C. 
2002b. "Estudo sobre os Fatores Determinantes do Sucesso elou Fracasso das Escolas Rurais dos Estados da Paraiba e do Maranhão." Washington, D.C.: World Bank, mimeo. 


\section{Appendix A: Poverty Indices and Inequality Measures based on PNAD 1981-99}

Table A1

\begin{tabular}{lrrrrrrrrr}
\hline P0 & 1981 & 1985 & 1988 & 1990 & 1993 & 1995 & 1997 & 1998 & 1999 \\
\hline Brazil & 24.4 & 26.0 & 25.1 & 30.3 & 29.7 & 21.8 & 21.9 & 21.6 & 22.4 \\
NE & 49.8 & 51.9 & 51.9 & 58.7 & 56.7 & 44.6 & 46.1 & 43.5 & 44.3 \\
São Paulo & 6.6 & 8.3 & 6.5 & 8.8 & 12.5 & 7.1 & 7.4 & 7.8 & 8.6 \\
Maranhão & 64.0 & 62.8 & 56.1 & 64.5 & 65.4 & 54.4 & 58.2 & 54.1 & 52.0 \\
Piauí & 69.3 & 69.8 & 68.1 & 71.5 & 62.1 & 51.6 & 57.6 & 50.2 & 51.8 \\
Ceará & 59.1 & 58.6 & 58.0 & 65.8 & 57.5 & 47.2 & 47.6 & 45.2 & 46.7 \\
Rio Grande do Norte & 49.4 & 55.7 & 47.7 & 57.0 & 54.5 & 40.4 & 39.8 & 38.3 & 39.7 \\
Paraíba & 58.3 & 57.0 & 57.4 & 60.7 & 56.9 & 40.8 & 42.9 & 40.5 & 39.4 \\
Pernambuco & 40.8 & 44.5 & 45.4 & 51.8 & 53.9 & 39.5 & 42.5 & 39.7 & 41.6 \\
Halagaos & 42.8 & 45.7 & 49.5 & 59.7 & 58.5 & 46.2 & 45.9 & 44.1 & 47.2 \\
Sergipe & 46.2 & 46.3 & 48.9 & 50.3 & 47.5 & 41.5 & 40.7 & 38.0 & 41.4 \\
Bahia & 40.7 & 44.7 & 47.7 & 54.9 & 54.6 & 43.0 & 43.5 & 41.5 & 42.2 \\
\hline
\end{tabular}

Table A2

\begin{tabular}{lrrrrrrrrr}
\hline P1 & $\mathbf{1 9 8 1}$ & $\mathbf{1 9 8 5}$ & $\mathbf{1 9 8 8}$ & $\mathbf{1 9 9 0}$ & $\mathbf{1 9 9 3}$ & $\mathbf{1 9 9 5}$ & $\mathbf{1 9 9 7}$ & $\mathbf{1 9 9 8}$ & $\mathbf{1 9 9 9}$ \\
\hline Brazil & 9.7 & 10.5 & 10.5 & 13.0 & 14.5 & 10.6 & 11.0 & 10.6 & 10.8 \\
NE & 22.0 & 23.8 & 24.1 & 28.5 & 30.0 & 21.4 & 22.4 & 20.7 & 21.2 \\
São Paulo & 2.0 & 2.6 & 2.1 & 2.7 & 5.8 & 4.4 & 4.8 & 4.6 & 4.8 \\
Maranhão & 31.1 & 29.7 & 26.4 & 34.2 & 37.5 & 28.9 & 31.5 & 27.2 & 24.2 \\
Piaú́ & 37.1 & 40.7 & 40.0 & 42.2 & 35.4 & 27.4 & 29.8 & 26.4 & 26.4 \\
Ceará & 27.9 & 27.9 & 28.1 & 33.1 & 30.2 & 23.0 & 23.1 & 21.9 & 22.7 \\
Rio Grande do Norte & 21.7 & 26.5 & 21.7 & 28.1 & 27.5 & 17.9 & 19.2 & 16.9 & 19.0 \\
Paraíba & 27.1 & 27.3 & 28.2 & 30.6 & 30.9 & 19.0 & 21.1 & 18.2 & 19.4 \\
Pernambuco & 16.1 & 19.2 & 19.9 & 23.0 & 28.0 & 17.4 & 20.0 & 18.5 & 20.0 \\
Halagaos & 16.8 & 17.8 & 20.9 & 25.4 & 31.0 & 20.9 & 21.7 & 20.6 & 21.8 \\
Sergipe & 18.3 & 18.8 & 20.9 & 20.8 & 23.6 & 19.8 & 20.5 & 18.0 & 20.0 \\
Bahia & 16.2 & 18.7 & 20.5 & 25.7 & 27.9 & 20.4 & 19.9 & 19.5 & 19.8 \\
\hline
\end{tabular}

Table A3

\begin{tabular}{lrrrrrrrrr}
\hline P2 & $\mathbf{1 9 8 1}$ & $\mathbf{1 9 8 5}$ & $\mathbf{1 9 8 8}$ & $\mathbf{1 9 9 0}$ & $\mathbf{1 9 9 3}$ & $\mathbf{1 9 9 5}$ & $\mathbf{1 9 9 7}$ & $\mathbf{1 9 9 8}$ & $\mathbf{1 9 9 9}$ \\
\hline Brazil & 5.2 & 5.7 & 6.0 & 7.4 & 9.8 & 7.2 & 7.7 & 7.3 & 7.5 \\
NE & 12.5 & 13.8 & 14.5 & 17.3 & 20.6 & 14.0 & 14.9 & 13.5 & 13.8 \\
São Paulo & 0.9 & 1.3 & 1.0 & 1.3 & 4.1 & 3.7 & 4.1 & 3.9 & 4.0 \\
Maranhão & 19.0 & 17.6 & 15.9 & 22.1 & 26.8 & 19.7 & 21.8 & 17.9 & 14.9 \\
Piauí & 24.2 & 28.3 & 28.3 & 29.7 & 25.6 & 19.1 & 20.5 & 17.7 & 17.7 \\
Ceará & 16.4 & 16.4 & 17.1 & 20.5 & 21.0 & 15.2 & 15.4 & 14.3 & 15.2 \\
Rio Grande do Norte & 11.9 & 15.7 & 12.7 & 16.9 & 18.2 & 11.2 & 13.2 & 10.6 & 12.6 \\
Paraíba & 15.7 & 16.2 & 17.5 & 19.2 & 21.6 & 12.3 & 14.1 & 11.4 & 12.7 \\
Pernambuco & 8.4 & 10.8 & 11.5 & 13.1 & 19.3 & 11.0 & 13.3 & 12.3 & 13.4 \\
Halagaos & 8.8 & 9.0 & 11.9 & 13.8 & 20.9 & 13.1 & 14.9 & 13.3 & 13.5 \\
Sergipe & 9.5 & 10.0 & 11.6 & 11.1 & 15.3 & 13.1 & 14.1 & 12.1 & 13.5 \\
Bahia & 8.4 & 10.1 & 11.6 & 15.0 & 18.7 & 13.2 & 12.7 & 12.7 & 12.8 \\
\hline
\end{tabular}




\section{Appendix B: Poverty Profiles}

Table B1: Poverty Profile for Brazil

\begin{tabular}{|c|c|c|c|c|c|c|c|c|c|c|}
\hline Brazil & & 1981 & 1985 & 1988 & 1990 & 1993 & 1995 & 1997 & 1998 & 1999 \\
\hline Total & & 24.4 & 26.0 & 25.1 & 30.3 & 29.7 & 21.8 & 21.9 & 21.6 & 22.4 \\
\hline \multirow{2}{*}{\multicolumn{11}{|c|}{ Gender }} \\
\hline & & & & & & & & & & \\
\hline & Male & 24.3 & 25.7 & 24.9 & 29.4 & 28.9 & 20.9 & 20.7 & 20.6 & 21.4 \\
\hline & Female & 25.1 & 27.0 & 26.1 & 34.1 & 32.5 & 24.9 & 25.5 & 24.3 & 25.2 \\
\hline \multicolumn{11}{|l|}{ Race } \\
\hline & White & & & 15.8 & 20.4 & 18.9 & 12.9 & 13.2 & 13.1 & 13.8 \\
\hline & Black & & & 34.1 & 42.3 & 36.7 & 27.0 & 27.3 & 26.5 & 28.5 \\
\hline & Mulatto & & & 39.3 & 44.4 & 44.9 & 34.7 & 34.8 & 33.8 & 34.4 \\
\hline & Indig & & & & & 56.7 & 54.0 & 34.3 & 29.0 & 38.3 \\
\hline & Asian & & & 5.9 & 5.1 & 10.3 & 4.8 & 7.5 & 5.0 & 7.0 \\
\hline \multicolumn{11}{|l|}{ Age: } \\
\hline & $<25$ & 21.5 & 28.5 & 28.2 & 35.5 & 46.4 & 39.2 & 41.4 & 41.5 & 42.3 \\
\hline & 25 to 45 & 26.4 & 27.7 & 26.5 & 30.0 & 33.2 & 25.0 & 24.4 & 24.8 & 26.2 \\
\hline & 45 to 65 & 22.4 & 23.8 & 22.5 & 27.0 & 25.4 & 17.9 & 18.0 & \begin{tabular}{|l|}
17.4 \\
\end{tabular} & \begin{tabular}{|l|}
17.8 \\
\end{tabular} \\
\hline & $>65$ & 23.7 & 22.8 & 24.7 & 36.8 & 15.3 & 9.5 & 11.4 & 8.9 & 9.1 \\
\hline \multicolumn{11}{|c|}{ Household Characteristics } \\
\hline & No. of $<5$ & 27.7 & 31.5 & 31.2 & 36.7 & 42.1 & \begin{tabular}{|l|}
33.4 \\
\end{tabular} & 39.2 & 33.9 & 35.6 \\
\hline & No of $5 \_15$ & 23.7 & 26.1 & 25.5 & 29.6 & 31.7 & 22.4 & 25.3 & 22.7 & 24.6 \\
\hline & No.of $>65$ & 22.4 & 22.5 & 24.5 & 33.8 & 18.1 & 11.5 & 12.5 & \begin{tabular}{|l|}
10.7 \\
\end{tabular} & 11.5 \\
\hline \multicolumn{11}{|c|}{ Location: } \\
\hline & Urban & \begin{tabular}{|l|}
15.9 \\
\end{tabular} & 18.0 & \begin{tabular}{|l|}
17.3 \\
\end{tabular} & 22.0 & 24.4 & \begin{tabular}{|l|}
16.7 \\
\end{tabular} & \begin{tabular}{|l|}
17.2 \\
\end{tabular} & \begin{tabular}{|l|}
17.1 \\
\end{tabular} & \begin{tabular}{|l|}
18.1 \\
\end{tabular} \\
\hline & Rural & \begin{tabular}{|l|}
48.7 \\
\end{tabular} & \begin{tabular}{|l|}
50.0 \\
\end{tabular} & \begin{tabular}{|l|}
50.3 \\
\end{tabular} & \begin{tabular}{|l|}
56.9 \\
\end{tabular} & \begin{tabular}{|l|}
52.2 \\
\end{tabular} & \begin{tabular}{|l|}
43.8 \\
\end{tabular} & \begin{tabular}{|l|}
43.7 \\
\end{tabular} & \begin{tabular}{|l|}
41.1 \\
\end{tabular} & \begin{tabular}{|l|}
41.7 \\
\end{tabular} \\
\hline \multicolumn{11}{|c|}{ Working Class: } \\
\hline & Carteira & & & & & & & & & \\
\hline & Yes & 11.0 & 13.3 & 12.4 & 18.7 & 18.4 & 11.3 & 10.2 & 10.3 & 10.7 \\
\hline & No & 41.7 & 41.4 & 40.9 & 43.6 & 51.5 & 34.8 & 33.6 & 33.8 & 34.7 \\
\hline & Active & & & & & & & & & \\
\hline & Yes & & & & 29.2 & 30.3 & 22.1 & 21.7 & 21.9 & 22.9 \\
\hline & No & & & & 35.1 & 26.8 & 20.8 & 22.5 & 20.4 & 20.7 \\
\hline & Worked & & & & & & & & & \\
\hline & Yes & 24.3 & 26.2 & 24.7 & 28.8 & 28.8 & 20.2 & 19.6 & 19.8 & 20.6 \\
\hline & No & 25.0 & 24.9 & 26.6 & 35.8 & 32.4 & 26.7 & 28.1 & 26.3 & 27.1 \\
\hline \multicolumn{11}{|c|}{ Work Sector: } \\
\hline & Agri. & 47.6 & 51.8 & 54.1 & 59.0 & 51.1 & 45.1 & 44.8 & 43.4 & 43.7 \\
\hline & Ind. & 17.7 & 16.8 & 15.5 & 20.4 & 24.2 & 13.3 & 13.9 & 15.4 & 16.3 \\
\hline & Service & 14.3 & 17.5 & 16.3 & 20.4 & 22.3 & 13.6 & 13.3 & 13.6 & \begin{tabular}{|l|}
14.4 \\
\end{tabular} \\
\hline & Social & 9.7 & 10.9 & 11.8 & 16.0 & 14.2 & 10.0 & 9.0 & 8.3 & 8.2 \\
\hline & Public & 10.5 & 13.6 & 13.1 & 16.9 & 19.3 & 10.4 & 8.7 & 8.8 & 7.8 \\
\hline & Other & 5.7 & 9.2 & 7.8 & 9.7 & 11.5 & 8.2 & 10.4 & 12.2 & 13.0 \\
\hline \multicolumn{11}{|c|}{ Work Position: } \\
\hline & Employee & 21.4 & 22.9 & 21.9 & 27.2 & 27.6 & 18.0 & 17.1 & 17.5 & 18.2 \\
\hline & self-employed & 33.0 & 36.1 & 34.1 & 37.1 & 34.5 & 26.7 & 26.2 & 26.1 & 26.8 \\
\hline & Employer & 4.7 & 5.1 & 4.3 & 8.2 & 6.7 & 3.6 & 3.6 & 3.1 & 3.8 \\
\hline & & & & & & & & & & \\
\hline & & & & & & & & & & \\
\hline
\end{tabular}




\begin{tabular}{|c|c|c|c|c|c|c|c|c|c|c|}
\hline Brazil (continued) & & 1981 & 1985 & 1988 & 1990 & 1993 & 1995 & 1997 & 1998 & 1999 \\
\hline \multicolumn{11}{|l|}{ Tenure } \\
\hline & $<1$ & & & & 28.7 & 28.8 & 20.4 & 19.8 & 19.9 & 20.6 \\
\hline & $>1$ & & & & 28.4 & 26.6 & $\mid 19.1$ & 18.7 & 18.6 & 19.3 \\
\hline & 1 to 3 & & & & 26.7 & 28.5 & 19.2 & 18.3 & 18.1 & 20.0 \\
\hline & 3 to 5 & & & & 23.9 & 26.6 & $\mid 17.8$ & 17.1 & $\mid 17.1$ & 17.3 \\
\hline & $>5$ & & & & 29.1 & 25.7 & 19.3 & 19.1 & 19.0 & 19.3 \\
\hline \multicolumn{11}{|l|}{ Education } \\
\hline \multicolumn{11}{|l|}{ Read and Write } \\
\hline & Yes & 15.9 & 17.8 & 17.2 & 21.6 & 24.3 & 17.1 & 17.3 & 17.3 & 18.4 \\
\hline & No & 47.7 & 50.3 & 52.2 & 60.5 & 51.8 & 41.6 & 43.7 & 41.6 & 41.8 \\
\hline \multicolumn{11}{|c|}{ Years of Schooling: } \\
\hline & no education or $<1$ & 45.5 & 48.1 & 48.9 & 58.4 & 48.5 & 38.8 & 39.9 & 38.5 & 38.6 \\
\hline & 1 to 4 & 29.9 & 33.0 & 32.6 & 38.7 & 33.1 & 23.9 & 25.0 & 24.6 & 25.9 \\
\hline & 4 to 8 & 13.2 & 16.5 & 17.4 & 22.9 & 28.3 & 20.3 & 22.4 & 21.5 & 23.5 \\
\hline & 8 to 12 & 3.8 & 5.3 & 6.7 & 9.5 & 14.2 & 9.4 & 10.1 & 10.8 & 11.7 \\
\hline & more than 12 & 0.4 & 0.7 & 0.6 & 1.1 & 2.8 & 1.5 & 2.4 & 2.0 & 1.9 \\
\hline & NA & 12.1 & 15.2 & 12.5 & 41.9 & 26.7 & 14.4 & 18.4 & 16.1 & 24.6 \\
\hline \multicolumn{11}{|l|}{ Waste Disposal } \\
\hline & Collected & 8.4 & 11.3 & 11.0 & 15.9 & 19.8 & 13.2 & 14.7 & 14.9 & 16.4 \\
\hline & Burnt & 29.1 & 33.6 & 36.7 & 46.2 & 45.4 & 37.1 & 40.1 & 39.6 & 40.9 \\
\hline & dumped on unused land, river, sea & 44.6 & 46.8 & 49.1 & 62.2 & 62.4 & 52.3 & 56.0 & 54.6 & 55.7 \\
\hline & Other & 9.1 & 12.2 & 7.3 & 11.4 & 40.4 & 36.9 & 35.2 & 37.1 & 41.6 \\
\hline \multicolumn{11}{|l|}{ Water Supply } \\
\hline & Piped & 11.6 & 14.9 & 14.7 & 19.9 & 19.7 & 13.2 & 14.4 & 20.8 & 21.7 \\
\hline & not piped & 34.9 & 41.7 & 42.1 & 50.8 & 27.0 & 20.5 & 20.4 & 14.7 & 15.9 \\
\hline & NA & 57.9 & 63.8 & 64.1 & 74.4 & 62.6 & 53.4 & 57.7 & 55.3 & 56.8 \\
\hline \multicolumn{11}{|l|}{ Sanitation } \\
\hline & Sew.Sys. \& Sep. Tank 1 & 4.6 & 7.3 & 7.0 & 10.9 & 13.7 & 8.6 & 9.4 & 9.8 & 10.7 \\
\hline & Septic Tank 2 & 9.5 & 11.8 & 12.9 & 18.1 & 25.5 & 17.3 & 19.6 & 19.4 & 19.0 \\
\hline & Rudimental Cespit & 28.0 & 32.6 & 35.7 & 43.8 & 40.6 & 31.4 & 33.6 & 32.2 & 34.7 \\
\hline & Drain & & & & & 43.7 & 33.8 & 37.1 & 38.5 & 36.3 \\
\hline & River or Lake & & & & & 33.7 & 21.9 & 24.9 & 26.5 & 26.6 \\
\hline & Other & 22.2 & 28.0 & 27.5 & 34.6 & 64.9 & 49.8 & 40.4 & 42.4 & 44.1 \\
\hline & NA & 85.1 & 0.0 & & 53.3 & 33.4 & 18.1 & 0.0 & 29.2 & 19.9 \\
\hline & None & 60.5 & 65.7 & 67.0 & 76.4 & & & & & \\
\hline \multicolumn{11}{|l|}{ Electricity } \\
\hline & Yes & 14.0 & 17.4 & 18.5 & 24.1 & 25.7 & 18.5 & 19.3 & 19.3 & 20.4 \\
\hline & No & \begin{tabular}{|l|}
56.2 \\
\end{tabular} & 62.6 & \begin{tabular}{|l|}
66.4 \\
\end{tabular} & 75.1 & 67.3 & 60.1 & \begin{tabular}{|l|}
61.8 \\
\end{tabular} & 59.9 & 60.1 \\
\hline \multicolumn{11}{|l|}{ Fridge: } \\
\hline & Yes & 8.1 & 10.3 & 11.4 & 16.0 & 17.9 & 12.2 & 14.2 & 14.6 & 15.6 \\
\hline & No & 46.4 & \begin{tabular}{|l|}
52.3 \\
\end{tabular} & 55.4 & 65.2 & 60.1 & 50.4 & 55.4 & 53.5 & 55.6 \\
\hline \multicolumn{11}{|l|}{ Cooker: } \\
\hline & Yes & 21.7 & 24.0 & 24.1 & 28.8 & 29.1 & 21.3 & 21.5 & 21.3 & 22.2 \\
\hline & No & 60.0 & \begin{tabular}{|l|}
63.1 \\
\end{tabular} & 61.3 & 73.2 & 61.6 & \begin{tabular}{|l|}
54.3 \\
\end{tabular} & 52.3 & 48.3 & 49.7 \\
\hline \multicolumn{11}{|l|}{ Radio: } \\
\hline & Yes & & & 20.4 & 25.1 & 25.4 & \begin{tabular}{|l|}
19.1 \\
\end{tabular} & 19.7 & 19.5 & 20.3 \\
\hline & No & & & 47.5 & 58.6 & 54.6 & 43.4 & 43.3 & 41.5 & 41.4 \\
\hline \multicolumn{11}{|l|}{ TV: } \\
\hline & Yes & & & 13.5 & 18.2 & 21.0 & 15.6 & 17.8 & 17.9 & 18.9 \\
\hline & No & & & 54.9 & 64.2 & 57.5 & 48.9 & 49.9 & 48.1 & 48.3 \\
\hline
\end{tabular}




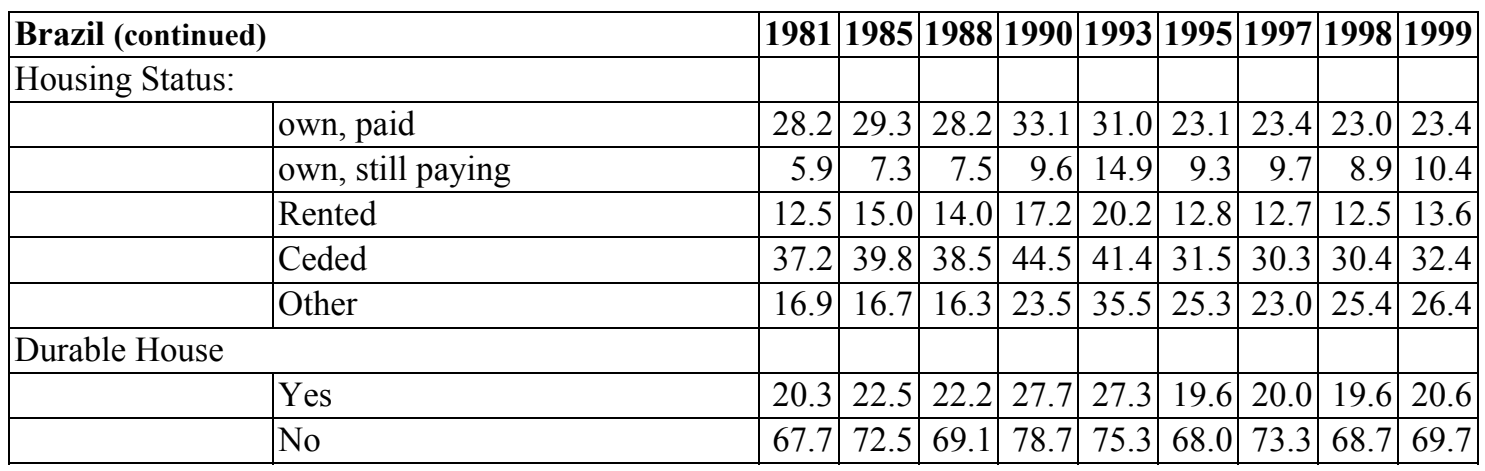


Table B2: Poverty Profile for Northeast

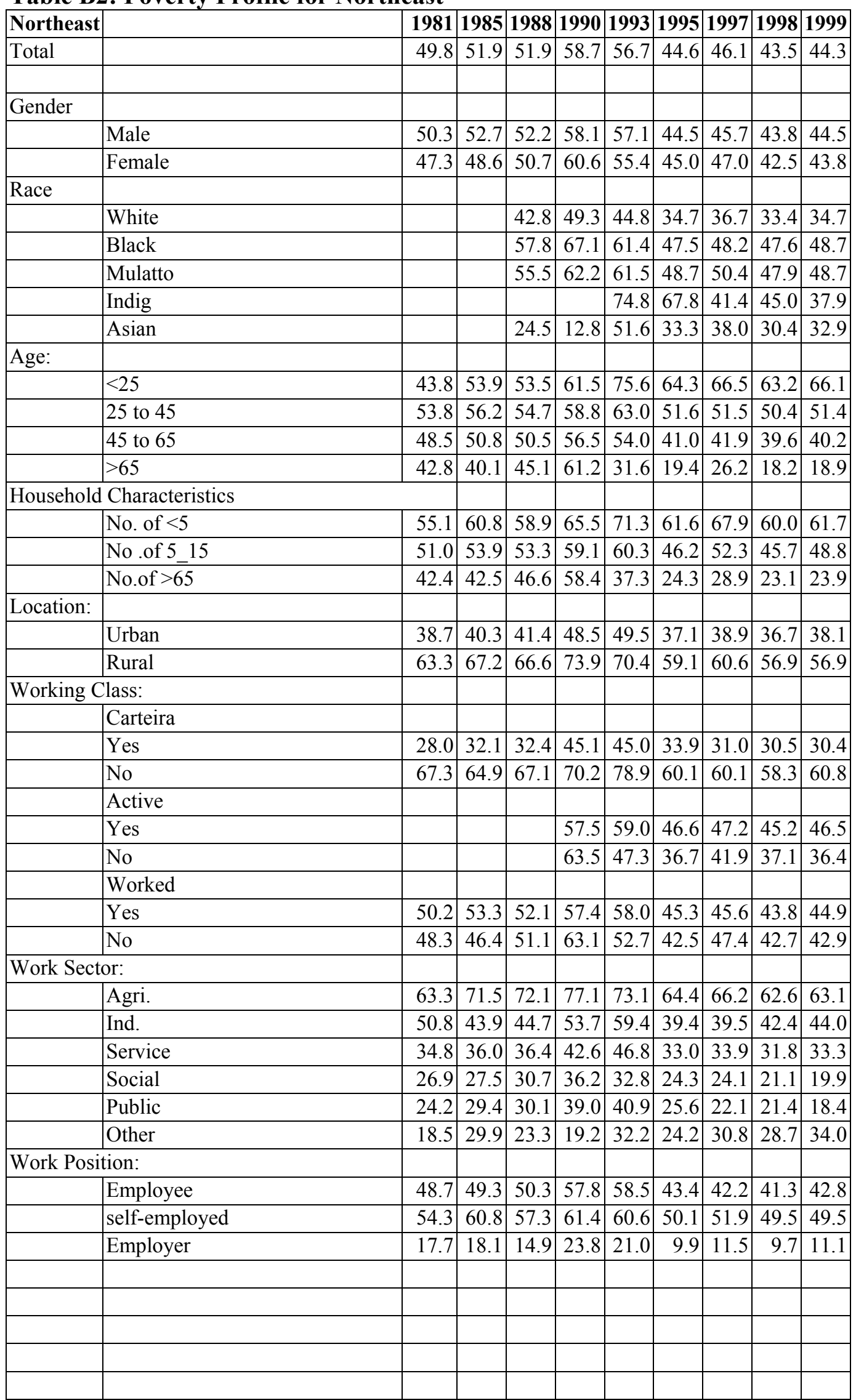




\begin{tabular}{|c|c|c|c|c|c|c|c|c|c|c|}
\hline Northeast & & $\mid 1981$ & 1985 & 1988 & 1990 & 1993 & 1995 & 1997 & 1998 & 1999 \\
\hline \multicolumn{11}{|l|}{ Tenure } \\
\hline & $<1$ & & & & 57.2 & 57.9 & 45.3 & 45.8 & 43.7 & 44.8 \\
\hline & $>1$ & & & & 56.3 & \begin{tabular}{|l|}
54.8 \\
\end{tabular} & 43.2 & 44.4 & 41.8 & 43.3 \\
\hline & 1 to 3 & & & & 54.8 & 59.8 & 45.1 & 45.7 & 41.7 & 45.3 \\
\hline & 3 to 5 & & & & 51.7 & 55.1 & 43.9 & 43.9 & 41.4 & 41.9 \\
\hline & $>5$ & & & & 56.8 & 53.1 & 42.5 & 44.2 & 42.1 & 42.6 \\
\hline \multicolumn{11}{|l|}{ Education } \\
\hline \multicolumn{11}{|c|}{ Read and Write } \\
\hline & Yes & 36.9 & 39.4 & 38.9 & 44.4 & 49.4 & 37.9 & 38.4 & 36.9 & 38.5 \\
\hline & No & 63.1 & 65.1 & 68.1 & 76.4 & 68.3 & 55.5 & 59.6 & 55.5 & 55.2 \\
\hline \multicolumn{11}{|c|}{ Years of Schooling: } \\
\hline & No education or $<1$ & 62.5 & 65.0 & 66.9 & 75.5 & 66.8 & 54.2 & 57.6 & \begin{tabular}{|l|}
54.2 \\
\end{tabular} & 53.7 \\
\hline & 1 to 4 & 53.9 & 57.5 & 57.9 & 64.8 & 64.2 & 50.0 & 52.6 & 50.0 & 52.1 \\
\hline & 4 to 8 & 32.3 & 35.9 & 38.8 & 47.4 & 54.2 & 43.1 & 46.4 & 42.8 & 45.0 \\
\hline & 8 to 12 & 10.5 & 13.5 & 17.4 & 22.3 & 29.7 & 20.2 & 22.5 & 21.6 & 23.0 \\
\hline & more than 12 & 1.4 & 1.6 & 2.0 & 3.4 & 7.3 & 3.8 & 3.5 & 3.3 & 2.9 \\
\hline & NA & 25.5 & 27.2 & 31.4 & 57.9 & 56.2 & 37.8 & 49.2 & 46.2 & 53.0 \\
\hline \multicolumn{11}{|c|}{ Waste Disposal } \\
\hline & Collected & 25.8 & 29.2 & 30.3 & 38.6 & 42.9 & 31.2 & 34.0 & 32.4 & 34.7 \\
\hline & Burnt & 53.5 & 55.3 & 58.1 & 65.6 & 69.2 & 56.7 & 60.8 & \begin{tabular}{|l|}
57.6 \\
\end{tabular} & 57.9 \\
\hline & dumped on unused land, river, sea & 57.6 & 57.5 & 62.0 & 74.2 & 71.4 & 59.7 & 63.4 & 60.4 & 60.2 \\
\hline & Other & 13.3 & 26.0 & 13.7 & 34.8 & 60.4 & 51.2 & 52.8 & 54.5 & 62.4 \\
\hline \multicolumn{11}{|c|}{ Water Supply } \\
\hline & Piped & 30.7 & 34.0 & 35.5 & 43.6 & 42.0 & 30.9 & 33.3 & 35.9 & 37.8 \\
\hline & not piped & 51.8 & 62.1 & 62.1 & 70.8 & 43.5 & 37.4 & 35.9 & 32.1 & 33.7 \\
\hline & NA & 65.3 & \begin{tabular}{|l|}
69.1 \\
\end{tabular} & 70.5 & 79.5 & 72.5 & 60.7 & 65.2 & 61.7 & 62.3 \\
\hline \multicolumn{11}{|c|}{ Sanitation } \\
\hline & Sew.Sys. \& Sep. Tank 1 & 13.6 & 14.7 & 17.9 & 26.5 & 30.7 & 23.2 & 24.3 & 23.0 & 24.8 \\
\hline & Septic Tank 2 & 19.1 & 23.1 & 27.9 & 34.9 & 40.7 & 30.8 & 31.5 & 31.2 & 31.0 \\
\hline & Rudimental Cespit & 43.2 & 45.6 & 48.1 & 58.2 & 57.9 & 43.8 & 47.8 & 44.6 & 47.1 \\
\hline & Drain & & & & & 68.4 & 50.7 & 56.8 & 55.7 & 54.4 \\
\hline & \multicolumn{2}{|l|}{ River or Lake } & & & & 60.1 & 39.1 & 44.3 & 39.3 & 46.8 \\
\hline & Other & 37.2 & 40.7 & 38.5 & 53.8 & 77.1 & 55.0 & 47.9 & 68.2 & 57.2 \\
\hline & NA & 100.0 & & & 52.0 & 47.2 & 0.0 & 0.0 & 0.0 & 36.7 \\
\hline & None & 66.2 & 71.1 & 73.4 & 80.5 & & & & & \\
\hline \multicolumn{11}{|l|}{ Electricity } \\
\hline & Yes & 34.3 & 37.9 & 41.5 & 49.4 & 51.4 & 39.6 & 42.0 & 39.8 & 41.3 \\
\hline & No & 66.3 & 72.1 & 73.5 & 81.5 & 74.6 & 64.8 & 67.5 & 65.0 & 63.7 \\
\hline \multicolumn{11}{|l|}{\begin{tabular}{|l|} 
Fridge: \\
\end{tabular}} \\
\hline & Yes & 21.1 & 23.4 & 26.5 & 33.2 & 37.1 & 27.4 & 31.9 & 30.7 & 32.1 \\
\hline & No & 61.9 & 66.3 & 68.5 & 77.2 & 72.9 & 60.9 & 66.1 & 62.3 & 63.8 \\
\hline \multicolumn{11}{|l|}{ Cooker: } \\
\hline & Yes & 45.4 & 48.6 & 50.3 & 56.0 & 56.0 & 43.8 & 45.5 & 43.0 & 43.9 \\
\hline & No & 66.2 & 69.9 & 69.9 & 80.5 & 71.5 & 63.6 & 65.1 & \begin{tabular}{|l}
59.6 \\
\end{tabular} & 61.8 \\
\hline \multicolumn{11}{|l|}{ Radio: } \\
\hline & Yes & & & 46.3 & 52.1 & 51.5 & 41.2 & 43.4 & 41.1 & 42.2 \\
\hline & No & & & 64.0 & 74.1 & 70.7 & 58.4 & 59.9 & 55.8 & 55.6 \\
\hline \multicolumn{11}{|l|}{ TV: } \\
\hline & Yes & & & 31.7 & 38.5 & 44.0 & 35.0 & 40.2 & \begin{tabular}{|l|}
38.1 \\
\end{tabular} & 39.3 \\
\hline & No & & & 68.5 & 77.5 & \begin{tabular}{|l|}
71.9 \\
\end{tabular} & 61.0 & 63.0 & \begin{tabular}{|l}
60.2 \\
\end{tabular} & 60.5 \\
\hline
\end{tabular}




\begin{tabular}{|c|c|c|c|c|c|c|c|c|c|}
\hline \multirow{2}{*}{\multicolumn{10}{|c|}{\begin{tabular}{ll|l|l|l|l|l|l|l|l|l|l|l|l|l|l|}
1981 & 1985 & 1988 & 1990 & 1993 & 1995 & 1997 & 1998 & 1999 \\
\end{tabular}}} \\
\hline & & & & & & & & & \\
\hline own, paid & 54.2 & 55.7 & 55.5 & 61.7 & 58.3 & 45.9 & 48.2 & 45.1 & 45.3 \\
\hline own, still paying & 13.3 & 17.0 & 15.8 & 21.4 & 27.4 & 17.2 & 18.5 & 14.9 & 17.0 \\
\hline Rented & 31.5 & 35.0 & 36.7 & 44.1 & 44.8 & 31.1 & 30.6 & 29.3 & 31.4 \\
\hline Ceded & 58.5 & 63.1 & 64.2 & 71.6 & 69.9 & 58.4 & 57.7 & 56.8 & 59.4 \\
\hline Other & 27.6 & 31.3 & 32.3 & 46.8 & 64.8 & 44.8 & 41.5 & 40.2 & 43.3 \\
\hline \multicolumn{10}{|l|}{ Durable House } \\
\hline Yes & 43.7 & 46.5 & 47.5 & 54.5 & 53.3 & 41.1 & 43.0 & 40.1 & 41.5 \\
\hline No & 75.0 & \begin{tabular}{|l|l}
79.0 \\
\end{tabular} & \begin{tabular}{|l|l}
71.9 \\
\end{tabular} & 85.7 & 80.5 & 71.3 & 77.6 & 74.5 & 71.8 \\
\hline
\end{tabular}


Table B3: Poverty Profile for Paraíba

\begin{tabular}{|c|c|c|c|c|c|c|c|c|c|c|}
\hline Paraíba & & 1981 & 1985 & 1988 & 1990 & 1993 & 1995 & 1997 & 1998 & 1999 \\
\hline Total & & 58.3 & 57.0 & 57.4 & 60.7 & 56.9 & 40.8 & 42.9 & 40.5 & 39.4 \\
\hline & & & & & & & & & & \\
\hline \multicolumn{11}{|l|}{ Gender } \\
\hline & Male & 59.1 & 58.2 & 58.4 & 59.7 & 57.0 & 39.9 & 42.5 & 41.6 & 39.3 \\
\hline & Female & 54.1 & \begin{tabular}{|l|}
51.4 \\
\end{tabular} & 53.4 & 63.6 & 56.4 & 43.4 & 43.9 & 37.2 & 39.7 \\
\hline \multicolumn{11}{|l|}{ Race } \\
\hline & White & & & 51.0 & 53.4 & 44.5 & 32.3 & 35.1 & 32.0 & 30.9 \\
\hline & Black & & & 61.9 & 73.6 & 58.5 & 56.4 & 56.2 & 54.2 & 45.2 \\
\hline & Mulatto & & & 63.2 & 64.9 & 63.9 & 44.4 & 48.1 & 46.0 & 47.3 \\
\hline & & & & & & & & & & \\
\hline & & & & & & & & & & \\
\hline \multicolumn{11}{|l|}{ Age: } \\
\hline & $<25$ & 49.1 & \begin{tabular}{|l|}
59.0 \\
\end{tabular} & 54.8 & 68.6 & 81.2 & 64.5 & 65.3 & 60.5 & 63.2 \\
\hline & 25 to 45 & 60.9 & 60.5 & 60.3 & 60.6 & 64.7 & 49.5 & 49.1 & 47.1 & 45.5 \\
\hline & 45 to 65 & 60.7 & 59.6 & 59.8 & 58.8 & 57.0 & 37.1 & 37.7 & 39.7 & 37.3 \\
\hline & $>65$ & 50.5 & 43.2 & 48.1 & 60.9 & 25.5 & 18.2 & 25.7 & 15.2 & 19.9 \\
\hline \multicolumn{11}{|c|}{ Household Characteristics } \\
\hline & No. of $<5$ & 59.6 & 61.2 & 67.7 & 65.6 & 69.5 & 60.5 & 69.6 & 53.3 & 55.0 \\
\hline & No .of $5 \_15$ & 58.8 & 57.5 & 61.0 & 61.9 & 60.3 & 42.9 & 47.4 & 42.8 & 44.6 \\
\hline & No.of $>65$ & 45.5 & 49.1 & 50.9 & 61.8 & 36.9 & 25.4 & 29.0 & 19.2 & 27.0 \\
\hline \multicolumn{11}{|l|}{ Location: } \\
\hline & Urban & 44.0 & 44.9 & 45.7 & 50.3 & 48.1 & 30.9 & 34.7 & 31.8 & 29.8 \\
\hline & Rural & 82.8 & 79.4 & 80.3 & 83.5 & 75.4 & 61.9 & 63.0 & 59.8 & 62.0 \\
\hline \multicolumn{11}{|c|}{ Working Class: } \\
\hline & Carteira & & & & & & & & & \\
\hline & Yes & 34.6 & 34.8 & 38.1 & 47.7 & 44.3 & 34.5 & 29.2 & 25.6 & 26.8 \\
\hline & No & 79.5 & 75.6 & 73.7 & 75.5 & 84.2 & 64.3 & 60.5 & 60.8 & 63.1 \\
\hline & Active & & & & & & & & & \\
\hline & Yes & & & & 59.9 & 58.9 & 43.0 & 44.0 & 42.6 & 41.2 \\
\hline & No & & & & 63.0 & 49.7 & 33.5 & 38.9 & 33.6 & 33.6 \\
\hline & Worked & & & & & & & & & \\
\hline & Yes & \begin{tabular}{|c|}
59.4 \\
\end{tabular} & \begin{tabular}{|l|}
59.3 \\
\end{tabular} & 58.9 & 59.8 & 57.6 & 42.1 & 41.9 & 41.7 & 40.0 \\
\hline & No & 55.3 & 50.0 & 52.7 & 62.9 & 55.1 & 37.2 & 45.5 & 37.2 & 38.0 \\
\hline \multicolumn{11}{|c|}{ Work Sector: } \\
\hline & Agri. & 75.6 & 81.8 & 81.9 & 82.7 & 73.5 & 62.7 & 64.6 & 64.6 & 59.6 \\
\hline & Ind. & 69.2 & \begin{tabular}{|c|}
56.8 \\
\end{tabular} & 59.0 & 62.2 & 60.4 & 40.1 & 34.5 & 43.5 & 52.9 \\
\hline & Service & 39.5 & 37.1 & 42.1 & 43.6 & 46.3 & 26.8 & 30.4 & 25.4 & 26.8 \\
\hline & Social & \begin{tabular}{|l|}
28.7 \\
\end{tabular} & 28.4 & 31.4 & 43.5 & 29.3 & 25.8 & 17.9 & 24.2 & 14.0 \\
\hline & Public & 32.9 & 33.6 & 31.2 & 39.6 & 51.4 & 19.0 & 20.0 & 21.5 & 12.6 \\
\hline & Other & 15.0 & 11.8 & 42.8 & 21.7 & 7.1 & 0.0 & 10.0 & 0.0 & 4.5 \\
\hline \multicolumn{11}{|c|}{ Work Position: } \\
\hline & Employee & 61.3 & 61.1 & 59.5 & 63.8 & 61.1 & 45.7 & 41.4 & 40.2 & 41.0 \\
\hline & self-employed & 56.6 & 59.5 & 60.7 & 59.1 & 57.7 & 42.0 & 47.0 & 46.5 & 42.7 \\
\hline & Employer & 20.0 & 26.1 & 41.2 & 27.0 & 19.1 & 10.5 & 10.2 & 3.8 & 0.0 \\
\hline & & & & & & & & & & \\
\hline & & & & & & & & & & \\
\hline & & & & & & & & & & \\
\hline & & & & & & & & & & \\
\hline & & & & & & & & & & \\
\hline
\end{tabular}




\begin{tabular}{|c|c|c|c|c|c|c|c|c|c|c|}
\hline Paraíba & & 1981 & 1985 & 1988 & 1990 & 1993 & 1995 & 1997 & 1998 & 1999 \\
\hline \multicolumn{11}{|l|}{ Tenure } \\
\hline & $<1$ & & & & 59.5 & 57.9 & 42.5 & 42.2 & \begin{tabular}{|l|}
41.6 \\
\end{tabular} & 39.8 \\
\hline & $>1$ & & & & 57.6 & 53.6 & 40.8 & 41.5 & 40.1 & 38.7 \\
\hline & 1 to 3 & & & & 61.2 & 50.3 & 44.8 & 47.6 & 42.0 & 47.8 \\
\hline & 3 to 5 & & & & 58.5 & 55.6 & 43.2 & 48.4 & 38.8 & 39.1 \\
\hline & $>5$ & & & & 56.7 & 53.8 & 39.3 & 39.6 & 39.5 & 35.4 \\
\hline \multicolumn{11}{|c|}{ Education } \\
\hline \multicolumn{11}{|c|}{ Read and Write } \\
\hline & yes & 41.1 & 40.2 & 44.5 & 44.9 & 48.5 & 32.4 & 33.6 & 31.3 & 31.2 \\
\hline & No & 72.4 & 73.8 & 72.2 & 79.0 & 69.3 & 52.6 & 58.8 & 56.3 & 53.8 \\
\hline \multicolumn{11}{|c|}{ Years of Schooling: } \\
\hline & No education or $<1$ & 71.4 & 73.9 & 71.4 & 78.9 & 67.2 & 51.0 & 54.6 & 55.2 & 51.3 \\
\hline & 1 to 4 & 66.4 & 61.9 & 65.6 & 66.9 & 63.0 & 44.7 & 51.2 & 45.7 & 49.5 \\
\hline & 4 to 8 & 38.5 & 38.2 & 47.4 & 49.7 & 65.0 & 36.4 & 36.1 & 35.7 & 39.9 \\
\hline & 8 to 12 & 14.1 & 15.4 & 25.1 & 29.4 & 36.7 & 19.3 & 24.3 & 19.8 & 19.5 \\
\hline & more than 12 & 4.6 & 4.1 & 5.4 & 4.2 & 10.7 & 2.1 & 4.0 & 3.4 & 2.7 \\
\hline & NA & 100.0 & 16.5 & 0.0 & & 25.0 & 0.0 & & 100.0 & 75.0 \\
\hline \multicolumn{11}{|c|}{ Waste Disposal } \\
\hline & collected & 38.9 & 38.6 & 38.7 & 45.4 & 44.1 & 27.3 & 32.9 & 30.3 & 30.0 \\
\hline & burnt & 72.6 & 78.9 & 63.6 & 68.1 & 75.6 & 48.7 & 61.5 & 56.6 & 55.4 \\
\hline & dumped on unused land, river, sea & 67.7 & 72.3 & 75.3 & 79.7 & 75.6 & 61.2 & 63.8 & 62.7 & 64.5 \\
\hline & other & 33.0 & 33.3 & 0.0 & 50.1 & 54.5 & 70.0 & 54.3 & 0.0 & 69.4 \\
\hline \multicolumn{11}{|c|}{ Water Supply } \\
\hline & piped & 40.2 & 40.9 & 44.5 & 49.6 & 45.7 & 28.5 & 32.7 & 31.6 & 34.0 \\
\hline & not piped & 65.5 & 82.1 & 79.6 & 85.1 & 50.0 & 50.0 & 55.5 & 30.1 & 28.7 \\
\hline & NA & 79.0 & 78.5 & 77.6 & 83.4 & 76.5 & 63.1 & 63.7 & 64.1 & 64.2 \\
\hline \multicolumn{11}{|l|}{ Sanitation } \\
\hline & Sew.Sys. \& Sep. Tank 1 & 17.4 & 18.0 & 22.0 & 30.0 & 31.6 & 24.4 & 26.4 & 20.4 & 20.5 \\
\hline & Septic Tank 2 & 27.0 & 27.5 & 37.8 & 32.9 & 45.1 & 24.1 & 22.5 & 21.0 & 22.4 \\
\hline & Rudimental Cespit & 53.6 & 58.9 & 56.5 & 68.5 & 59.5 & 42.9 & 49.5 & 44.3 & 46.5 \\
\hline & Drain & & & & & 70.8 & 59.0 & 50.0 & 59.3 & 67.9 \\
\hline & River or Lake & & & & & 47.4 & 29.4 & 40.0 & 62.5 & 42.9 \\
\hline & Other & 50.0 & 36.4 & 44.4 & 62.3 & 0.0 & & 0.0 & 0.0 & 100.0 \\
\hline & NA & & & & & & & & & \\
\hline & none & 82.8 & 83.1 & 81.2 & 85.8 & & & & & \\
\hline \multicolumn{11}{|l|}{ Electricity } \\
\hline & yes & 41.8 & 44.1 & 48.8 & 52.8 & 52.5 & 37.5 & 42.1 & 39.2 & 38.5 \\
\hline & No & 80.0 & 81.4 & 80.6 & 89.7 & 77.3 & 67.3 & 58.3 & 68.7 & 66.2 \\
\hline \multicolumn{11}{|l|}{ Fridge: } \\
\hline & yes & 22.5 & 23.1 & 30.3 & 32.2 & 37.2 & 22.7 & 29.3 & 28.7 & 27.2 \\
\hline & No & 72.5 & 72.5 & 73.3 & 80.7 & 74.0 & 58.7 & 65.5 & \begin{tabular}{|l|}
63.4 \\
\end{tabular} & 66.4 \\
\hline \multicolumn{11}{|l|}{ Cooker: } \\
\hline & yes & 58.0 & 56.7 & 57.5 & 59.0 & 56.6 & 40.8 & 42.8 & \begin{tabular}{|l|}
40.2 \\
\end{tabular} & 39.3 \\
\hline & No & 60.9 & 65.4 & 57.8 & 85.5 & 75.0 & 32.3 & 47.6 & \begin{tabular}{|l|}
62.5 \\
\end{tabular} & 57.1 \\
\hline \multicolumn{11}{|l|}{ Radio: } \\
\hline & yes & & & 54.6 & 56.2 & 53.7 & 38.7 & \begin{tabular}{|l|}
41.3 \\
\end{tabular} & \begin{tabular}{|l|}
39.1 \\
\end{tabular} & 38.6 \\
\hline & No & & & 65.3 & 73.8 & \begin{tabular}{|l|}
69.7 \\
\end{tabular} & 53.2 & 55.9 & \begin{tabular}{|l|}
51.8 \\
\end{tabular} & 45.9 \\
\hline \multicolumn{11}{|l|}{ TV: } \\
\hline & yes & & & \begin{tabular}{|l|}
41.1 \\
\end{tabular} & 41.8 & \begin{tabular}{|l|}
46.4 \\
\end{tabular} & 33.7 & 41.0 & \begin{tabular}{|l|}
37.9 \\
\end{tabular} & 36.9 \\
\hline & No & & & \begin{tabular}{|l|}
73.4 \\
\end{tabular} & 83.4 & \begin{tabular}{|l|}
72.5 \\
\end{tabular} & 58.5 & $\begin{array}{l}54.1 \\
\end{array}$ & \begin{tabular}{|l|}
56.7 \\
\end{tabular} & 57.8 \\
\hline
\end{tabular}




\begin{tabular}{|l|l|r|r|r|r|r|r|r|r|r|}
\hline Paraíba & $\mathbf{1 9 8 1}$ & $\mathbf{1 9 8 5}$ & $\mathbf{1 9 8 8}$ & $\mathbf{1 9 9 0}$ & $\mathbf{1 9 9 3}$ & $\mathbf{1 9 9 5}$ & $\mathbf{1 9 9 7}$ & $\mathbf{1 9 9 8}$ & $\mathbf{1 9 9 9}$ \\
\hline Housing Status: & & & & & & & & & \\
\hline & own, paid & 62.4 & 61.3 & 62.9 & 63.1 & 58.0 & 41.4 & 42.8 & 41.7 & 39.0 \\
\hline & own, still paying & 11.5 & 15.7 & 21.9 & 23.6 & 30.6 & 12.3 & 21.1 & 14.5 & 18.8 \\
\hline & rented & 38.2 & 41.1 & 40.2 & 52.6 & 48.1 & 25.2 & 32.5 & 26.9 & 23.6 \\
\hline & ceded & 81.2 & 79.2 & 74.7 & 75.5 & 69.2 & 56.8 & 58.7 & 55.8 & 66.1 \\
\hline & other & 66.6 & 14.2 & 33.3 & 50.1 & 77.8 & 60.0 & 25.0 & 20.0 & 44.4 \\
\hline & & & & & & & & & \\
\hline Durable House & & 55.9 & 54.0 & 55.7 & 59.0 & 55.4 & 39.4 & 41.8 & 39.7 & 38.7 \\
\hline & Yes & 85.8 & 90.9 & 71.4 & 100.0 & 100.0 & & 100.0 & & \\
\hline
\end{tabular}


WB105749

C: $\backslash$ a- word $\backslash$ my papers $\backslash$ Paraiba paper $\backslash$ Paraiba education Final may19 05-wp.doc

May 20, 2004 3:31 PM 